\title{
Uncertainties in Rainfall and Water Resources in Maghreb Countries Under Climate Change
}

\author{
Mohamed Meddi and Saeid Eslamian
}

\section{Contents}

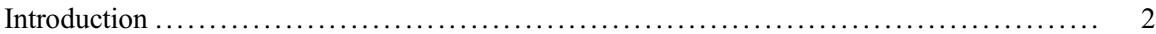

Maghreb Countries, Water Resources, and Climate Change $\ldots \ldots \ldots \ldots \ldots \ldots \ldots \ldots \ldots \ldots \ldots \ldots$

Climate Change, Future Projection, and Adaptation ................................. 7

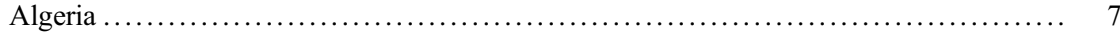

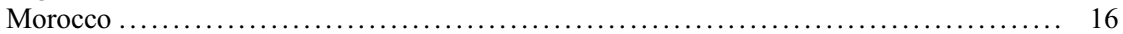

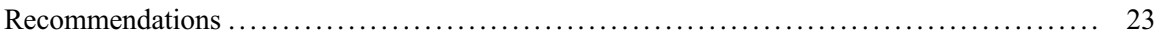

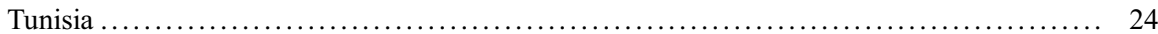

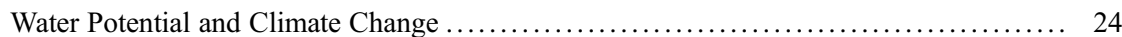

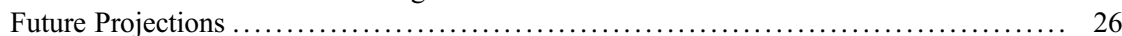

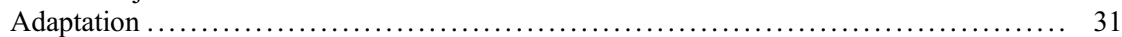

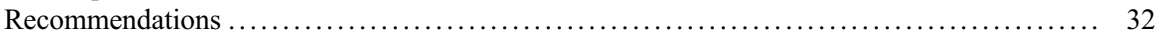

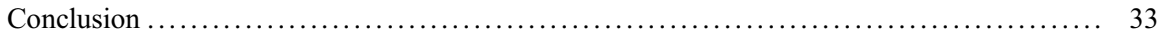

References $\ldots \ldots \ldots \ldots \ldots \ldots \ldots \ldots \ldots \ldots \ldots \ldots \ldots \ldots \ldots \ldots \ldots \ldots \ldots \ldots \ldots \ldots \ldots \ldots \ldots \ldots \ldots \ldots \ldots \ldots \ldots, \quad 34$

\section{Abstract}

The vulnerability of the climate change in the South of the Mediterranean's south regions varies depending on the part of their climate which is sensitive to the economy. In Tunisia, agriculture represents $16 \%$ of the workforce and $12 \%$ of GDP in 2006. In Algeria, agriculture represents $20 \%$ of the workforce and $8 \%$ of GDP in 2009. In Morocco, agriculture accounts for $40 \%$ of the workforce and $17.7 \%$ of GDP in 2006 . The agriculture is directly related to the availability of water which in turn is directly related to rainfall. The drought has affected all countries of the Maghreb. It is considered the most severe in the history of these

M. Meddi $(\bowtie)$

Ecole Nationale Supérieure d'Hydraulique de BLIDA, Boufarik, Algeria

e-mail: m.meddi@ensh.dz

S. Eslamian

Department of Water Engineering, College of Agriculture, Center of Excellence on Risk Management and Natural Hazards, Isfahan University of Technology, Isfahan, Iran e-mail: saeid@cc.iut.ac.ir 
countries. The drought has forced the agricultural sector in Morocco to the limitation of annual crops which are not needed, the prohibition of any new tree planting and the ban on vegetable crops in dry years. During the years 1987, 1988, and 1989, Tunisia has experienced the most critical drought. It led to a water deficit of around 30\%. For Morocco the rainfall shows a negative trend at national and regional scales, and spring rainfall has declined by over $40 \%$ since the 1960s. For Algeria, the western region has recorded a considerable reduction in rainfall. The winter rains have decreased between $40 \%$ and $70 \%$. Contributions to dams have decreased between $30 \%$ and $50 \%$. These changes had a negative influence on the water resource and crop yield. Many programs have been initiated since then to meet the growing demand.

\section{Keywords}

Rainfall $\cdot$ Water resources $\cdot$ Drought $\cdot$ Climate change $\cdot$ Maghreb countries

\section{Introduction}

The issue of climate change settled permanently at the forefront of the news and concerns opinion's public. Confined for a long time to the scientific community and environmental groups, it has emerged in recent years at a government level with the signing of the Kyoto Protocol. But it is mostly the recent weather disturbances (repeated heat waves, devastating hurricanes). Meanwhile, advances in scientific knowledge have gradually transformed what was originally a simple hypothesis - a global warming caused by man - a virtual certainty, although there are still many unknowns about the accurate scope and the pace of the phenomenon.

According to the World Bank (2017), Tunisia, Algeria, and Morocco will become global hot spots by the end of the twenty-first century. Higher temperatures and reduced precipitation will increase the occurrence of droughts in this region (World Bank 2017).

Droogers et al. (2012) found that climatic changes will be responsible for $22 \%$ of water shortages by 2050 and $78 \%$ of water shortages will be the result of socioeconomic factors for North Africa. During the last century, Algeria has experienced several periods of drought, the most intense were felt in 1910 and 1940 and more persistent in the years from 1975 to 1990 and the beginning of the century. The last drought in the Maghreb countries since five past decades is particularly severe. The period 1950-1975 was wetter comparing to the long-term average, so that from 1977 there is an enough marked drought, unprecedented since the early observations. Algeria and especially the West region have experienced several major droughts in the last century, during the 1940s and 1970s until today (Meddi and Hubert 2003; Habibi et al. 2018; Merabti et al. 2018). The latest one was characterized by its spatial extent and its intensity. In Morocco, droughts continue to increase in both frequency and intensity and impact negatively water resources and agricultural production according to World Bank (2017). Droughts are recurrent and are 
becoming more frequent and more severe. Previous recorded droughts, which required government emergency plans, were recorded in 1992-1995, 1998-2001, 2005, 2007, and 2015-2016. The 1994-1995 droughts were particularly strong, resulting in an estimated GDP loss of 7.6\% (World Bank Group 2017a). The 1999 drought cost about US\$900 million and affected more than one million hectares of cultivated land (World Bank Group 2017a).

To the large spatial variability of precipitations correspond a clear regional difference in the potential of surface water. At the seasonal and interannual variability of rainfall, there is also a strong irregular hydrographical inflow with violent floods and low water periods that can last several months (Meddi and Hubert 2003).

Two-thirds of the territory of Tunisia is characterized by a semiarid climate to arid. This space is subject to drought may be common. The droughts are a common natural phenomenon in Tunisia. They become more and more frequent. The resulting consequences have increasingly serious social and economic impacts. The droughts date back to the last century and Tunisia experienced 31 dry years between 1907 and 2016. More recently, Tunisia experienced a drought during the years: 1982, 1987 to 1989, 1993, 1994, 1995, 1997, 2000, 2001, 2002, 2008, 2010, 2013, and 2016, and the worst drought since more than 50 years was recorded during the years from 1999 to 2002. These droughts cost about $\$ 54$ million.

The agricultural sector is largely dependent on the availability of water resources, which is the most vulnerable to climate change (Farzaneh et al. 2014). In Algeria, the water consumption in the agricultural sector is about 7 billion $\mathrm{m}^{3} /$ year where it represents $70 \%$ of the total national consumption (http://www.mree.gov.dz). In Morocco, irrigation uses $80 \%$ of the country's mobilized resources, the rest being reserved for drinking water and industry (MDCE 2016). The used water in irrigation is about 12,038 million $\mathrm{m}^{3}$ (Dahan 2017). In Tunisia, the volume of water intended for irrigation id about $80 \%$ of total water consumption (Chebil et al. 2019). These volumes of water used in irrigation to ensure food security and socioeconomic development in these countries demonstrate the importance of studies and the proposal of scenarios on the impact of climate change on water resources in order to be able to propose measures meet the growing demand in the medium and long term.

Climate projections confirm reduction of rainfall and rising of temperatures (Matari 2016), which will affect the availability of water resources in the medium and long term, hence the need to find ways to mobilize additional water resources (conventional and unconventional) to meet this ever increasing demand.

In this chapter, we will discuss the effects of climate change on water resources as well as adaptation measures in the three Maghreb countries.

\section{Maghreb Countries, Water Resources, and Climate Change}

The three Maghreb countries (Algeria, Tunisia, and Morocco) occupy an area of $3,254,000 \mathrm{~km}^{2}$ (Fig. 1). The Maghreb is crossed from north to west by a mountain system called "Atlas." It is a barrier between the Mediterranean coast and the Sahara. It begins at the mouth of the Wadi Sous in southwestern Morocco to Cape Bon and 


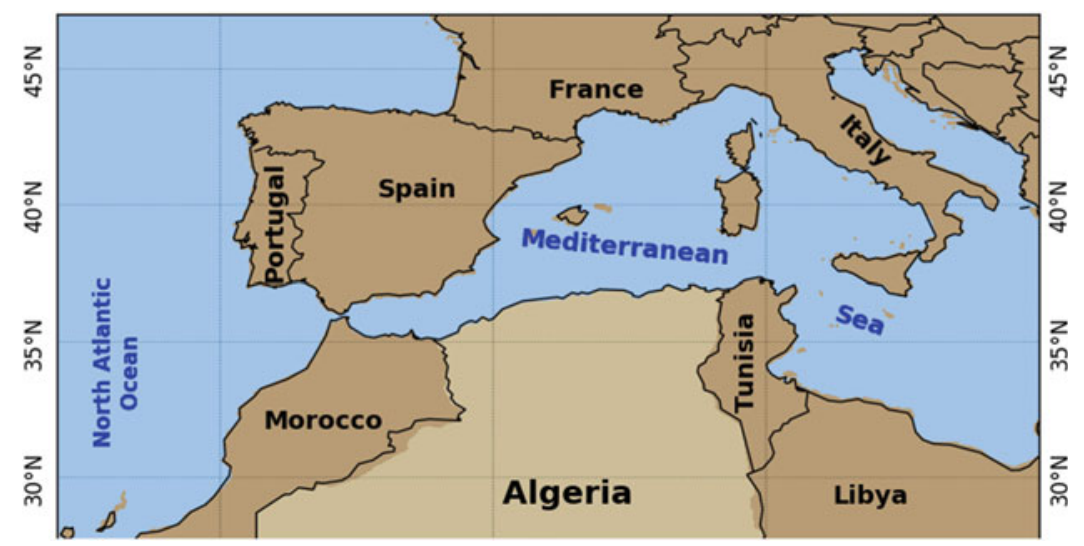

Fig. 1 Situation of Algeria, Tunisia, and Morocco (Zeroual et al. 2017)

the Gulf of Gabes in northeastern Tunisia. South of the Tell, there is the Saharan Atlas which separates the Algerian highlands from the Sahara. It continues its extension to the east by the Aurès and the Tunisian Dorsal. The Sahara occupies nearly 80 percent of the total area. The most fertile agricultural land is located on the coastal strip that separates the mountains from the sea and the highlands.

These three countries are characterized by considerable demographic growth. They are also facing the phenomenon of climate change which has led to a decrease in rainfall and an increase in temperatures. Rainfall in the Maghreb is already low, with average rainfall volumes of about $357 \mathrm{~km}^{3} /$ year, or $110 \mathrm{~mm}$ (Taabni and El Jihad 2015).

Tunisia is located between longitudes $7^{\circ}$ and $12^{\circ}$ east and $32^{\circ}$ and $38^{\circ}$ latitudes north. Humid to subhumid areas are in the north. The subhumid to semiarid regions are located in the northwest and the Cape Bon region. The semiarid to arid part is located in central Tunisia. The desert covers the south of Tunisia. In Tunisia, rainfall and temperatures vary considerably from north to south (humid coastal zone to desert conditions in the south) and from east to west. They are influenced by the Mediterranean Sea in the north and in the east and by the Sahara in the south and in the southwest. The rains fall mainly between the months of October and May. Temperatures in the arid and semiarid regions of the south and southwest of the country are generally high, while precipitation is much higher from November to April in the more northerly regions.

The northern part of Algeria is characterized by a Mediterranean climate with a relatively cold and rainy winter and a hot and dry summer. The annual rainfall reaches $400 \mathrm{~mm}$ in the west, $700 \mathrm{~mm}$ in the center, and $1000 \mathrm{~mm}$ in the east for the coast. This type of climate is also found in the Tellian Atlas chains where we record totals ranging from 800 to $1600 \mathrm{~mm}$ in the eastern summits, while the values are lowered in the center $(700$ to $1000 \mathrm{~mm})$ and in the west $(600 \mathrm{~mm})$. In the plains of the Tellian Atlas, rainfall varies between $500 \mathrm{~mm}$ in the west, $450 \mathrm{~mm}$ in the center, and $700 \mathrm{~mm}$ in the east (Meddi and Hubert 2003). 
In Morocco, rainfall follows a decreasing gradient from north to south and from west to east. Rainfall and temperatures are strongly influenced by the Atlantic Ocean to the west, the Mediterranean Sea to the north and the Sahara to the south and southeast. Most rainfall occurs between October and May like other Maghreb countries (World Bank Group 2017a). Morocco is characterized by spatial and temporal variability of rainfall. The northwest receives more rain than the rest of the country. The average annual rainfall varies considerably. It can reach more than $800 \mathrm{~mm}$ on the reliefs, while it hardly exceeds $300 \mathrm{~mm}$ on the adjacent plains (World Bank Group 2017).

The climate of Tunisia is strongly influenced by the Mediterranean Sea in the north and east and by the Sahara in the south and southwest. Like other Maghreb countries, rainfall occurs mainly between October and May. Rainfall varies considerably from a relatively wet coastal area to desert conditions in the south. Precipitation exceeds $400 \mathrm{~mm} / \mathrm{year}$ in the north and reaches $1500 \mathrm{~mm} / \mathrm{year}$ in the extreme northwest of Tunisia (TSNCUNFCCC 2013). In the central part of the country, precipitation varies between 150 and $300 \mathrm{~mm} /$ year (TSNCUNFCCC 2013). Rainfall is becoming scarce and less than $150 \mathrm{~mm} / \mathrm{year}$ and at the extreme south, rains not exceed $50 \mathrm{~mm} /$ year. The average total annual rainfall varies from 1 year to another and is around 36 billion $\mathrm{m}^{3} /$ year (TSNCUNFCCC 2013).

The decrease in rainfall since mid-1970s has negatively impacted the renewal of groundwater and the dams filling. The scarcity of water resources has had a dramatic effect on the economy in general and agricultural production and agricultural development in these countries in particular. Agriculture is largely dependent on rainfall. In Morocco, irrigated agriculture contributes about $45 \%$ of agricultural added value, despite, irrigated agriculture, occupying only $15 \%$ of cultivated area. In Algeria, according to the Ministry of Water Resources, the water consumption in the agricultural sector is close to 7 billion $\mathrm{m}^{3} /$ year where it represents $70 \%$ of the total national consumption which is of the order of 10.6 billion $\mathrm{m}^{3} /$ year (http://www. mree.gov.dz). The rate for agriculture corresponds to the world water consumption in irrigation which is around $70 \%$. In Morocco, irrigation uses $80 \%$ of the country's mobilized resources, mainly surface water, the rest being reserved for drinking water and industry (MDCE 2016). The used water in irrigation is about 12,038 million $\mathrm{m}^{3}$ (Dahan 2017). In Tunisia, the volume of water intended for irrigation about $80 \%$ of total water consumption (Chebil et al. 2019). This volume was in 2004 of about 2130 million $\mathrm{m}^{3}$ for an area of 375,000 ha and will be 2145 million $\mathrm{m}^{3}$ in 2011 and 2035 million $\mathrm{m}^{3}$ in 2030 for an area of 467,000 ha (www.environnement.gov.tn). In the future, rational pricing encourages farmers to use more and more water-saving technologies and varieties that consume less water.

The renewable water resources in the three Maghreb countries are estimated at $43 \mathrm{~km}^{3}$, where surface water accounts for $73 \%$ (Taabni and El Jihad 2015). In 2010, the average per capita renewable water provision for the Maghreb countries was 548 $\mathrm{m}^{3} /$ person/year in 2010, and by 2030 it will be less than $290 \mathrm{~m}^{3} /$ person/year (Taabni and El Jihad 2015). These values are well below the standard set by the World Health Organization (WHO) of $1000 \mathrm{~m}^{3} /$ person/year.

All these statistics show the importance of the development of water resources management scenarios in the Maghreb countries to meet the increase of water 
demand for drinking water supply and especially for irrigation, so to increase the capacity of agricultural productivities, and sustainable production systems to reduce the problem of poverty and unemployment knowing that the agricultural sector is the main employer in the world with $40 \%$ of the world population.

The Maghreb countries are located in an arid to semiarid region. The climate is Saharian in the southern, oceanic in the western, and Mediterranean in the north. The population of Morocco, Algeria, and Tunisia was already 65 million in 2000 and attended more than 75 million in 2010. A population that is gathered for more than two-thirds on the shores of the northern Atlantic and Mediterranean region, the life of people in these countries is closely linked to climate and to these changes.

Climate data recorded in the Maghreb region during the twentieth century indicate a warming in this century estimated at more than $1{ }^{\circ} \mathrm{C}$, despite its small share in global emission of greenhouse gases (GHGs) (www.anme.nat.tn). These data also show an increase in droughts and floods. Thus, we started a drought every 10 years at the beginning of the century to 5-6 years of drought in a decade now (Agoumi 2003).

The North African countries suffer from recurrent droughts, whose frequency has increased over the last 40 years. Increasing climate variability affects in particular the center and the north of these countries and the predictions of the Intergovernmental Panel on Climate Change (IPCC 2013) are worrying, even alarming. They indeed show a worsening trend for future decades (OSS 2009). The central Maghreb is characterized by a low average annual rainfall and strong fluctuations in rainfall. In recent decades, he suffered several episodes of drought and the latter tends to be more structural than cyclical. In years of drought, the scarcity of rainfall affects pluvial agriculture which occupies an important agricultural area in the region but also all other sectors dependent on water resources. Irrigated agriculture is also affected and measures of restrictions on water allocation are generally applied (OSS 2009).

Climate data recorded in the region during the twentieth century indicate a warming during this century estimated at more than $1{ }^{\circ} \mathrm{C}$ with an accentuated trend in the last 30 years (Fig. 2). These data also show a net increase in the frequency of droughts and floods. Thus, we started a drought every 10 years at the beginning of the century to 5-6 years of drought in a decade now. The general circulation models, even if they are not accurate enough for this region does not have a centered model converge to estimate a likely warming in the region of about $2^{\circ}$ to $4^{\circ}$ during the twenty-first century.

Trend analysis of rainfall variability in the Mediterranean region shows a significant decrease in rainfall from 1970 (Knippertz et al. 2003; New et al. 2001; Rodrigo and Trigo 2007; Khomsi et al. 2013). This downward trend is higher in winter (Jacobeit 2000; Giorgi 2002). In the Maghreb, Tramblay et al. (2013) observed a negative trend in precipitation intensity, in annual maximum precipitation, and in the 95th percentile of precipitation.

The vulnerability of the climate change in the Mediterranean's south regions varies depending on the part of their economy sensitive to climate (agriculture, tourism, infrastructures, energy, and ecosystem). In Tunisia, agriculture represents $16 \%$ of the workforce and $12 \%$ of GDP in 2006 (BCT 2007). After a decline of 7\% in 2005 caused by drought, its rate of growth was $2.5 \%$ in 2006 and $2.1 \%$ in 2007 . 


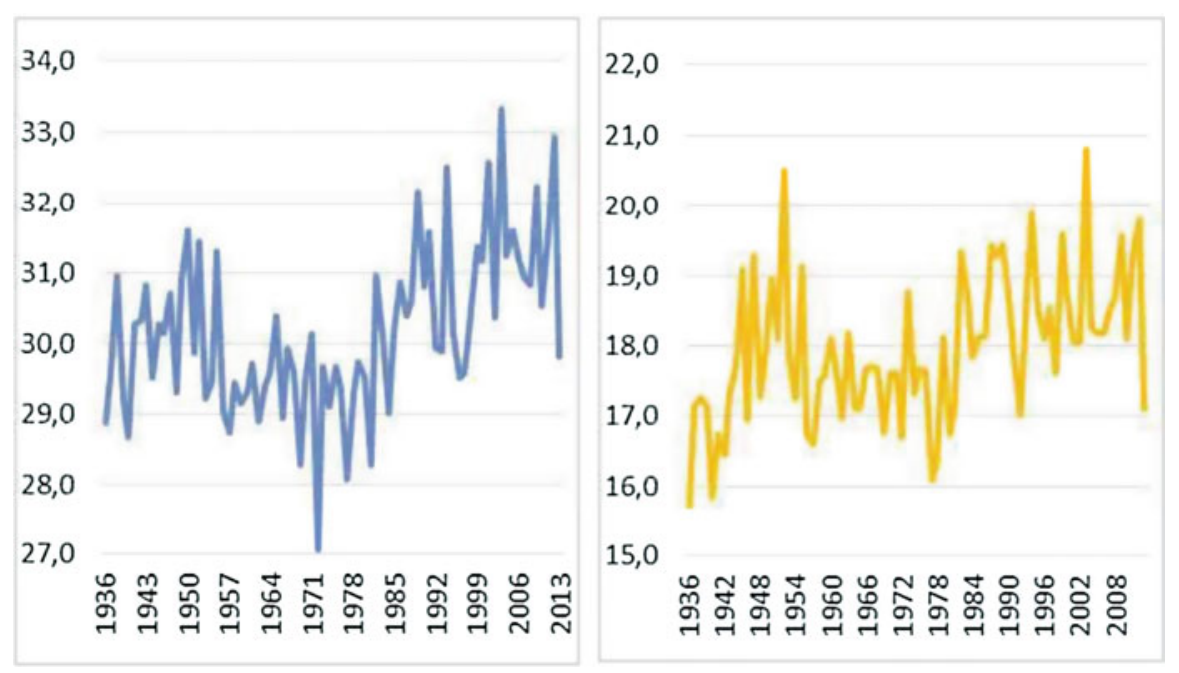

Fig. 2 Evolution of average maximum and minimum temperature in Algiers at Dar El Beida station 1936-2012 (Matari 2016)

For Algeria, agriculture represents 20\% of the workforce and 8\% of GDP in 2009. For Morocco, agriculture accounts for $40 \%$ of the workforce and $17.7 \%$ of GDP in 2006. This sector in these countries is directly related to the availability of water which in turn is directly related to rainfall.

\section{Climate Change, Future Projection, and Adaptation}

\section{Algeria}

\section{Water Potential and Climate Change}

Water potential of Algeria is estimated at 19.4 billion $\mathrm{m}^{3} /$ year according to the Ministry of Water Resources. The groundwater resources contained in the northern aquifers of the country (renewable resources) are estimated at 2 billion $\mathrm{m}^{3} /$ year and the surface water is estimated at 12 billion $\mathrm{m}^{3} /$ year. The water reserves of southern Algeria are very important and are of the order of 40,000 billion, this resource is not renewable according to the Ministry of Water Resources.

Water and its management represent a major problem in Algeria following specially in the South. It is amplified by the reduction of rainfall affecting the country since the 1970s. For example, the rainfall, in the northwest, decreases more than $20 \%$ (Figs. 2 and 3) and the temperature has increased as shown in Fig. 3. Droughts in rehearsing raise represent the most serious concerns for citizens and managers of the water sector. The climate scenarios and the availability of water are alarming and might have direct and indirect bad consequences on the potential of water resources (quantity and quality) and on their use in the Drinking Water Supply, in agriculture, and in industry. 

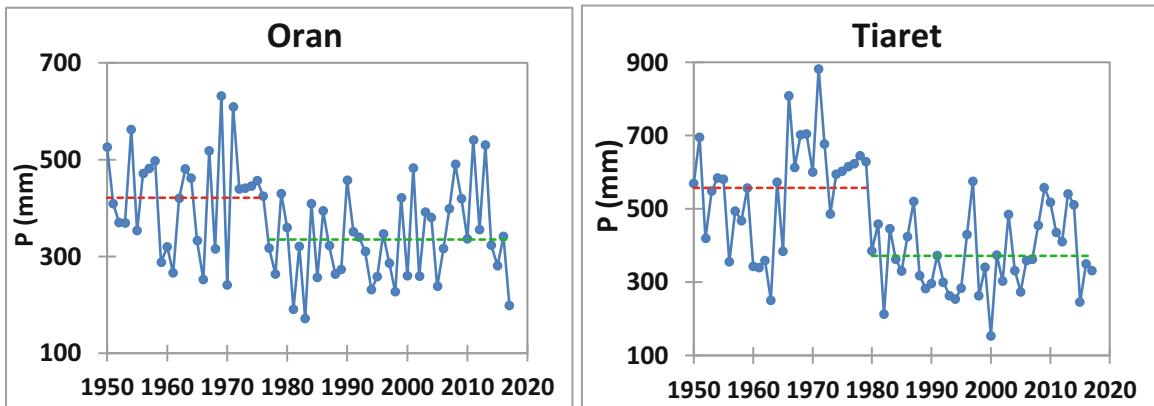

Fig. 3 Trend of annual rainfall variability at Oran and Tiaret stations

Water resources in Algeria are limited, vulnerable, and unevenly distributed in terms of geography. Many dams have been constructed to develop surface water storage capacity, whereas in 1962 there were only 13 dams capable of storing 450 million cubic meters of water, mainly used for irrigation of the plains in the west of the country (http://anbt-dz.com/). The storage capacity has multiplied several times and has reached eighty dams with a capacity of more than eight billion cubic meters in 2017 .

According to the Ministry of Water Resources (http://www.mree.gov.dz), drinking water supply, after being confined in big cities, the network connection rate has increased from $78 \%$ in 1999 to $98 \%$ in 2017 . The network is over $127,000 \mathrm{~km}$ in 2017. The increase in water availability per capita has increased from 1231 in 1999 to 1801 in 2017 , but water distribution systems still lose about one-third of the water distributed due to leaks.

\section{Immediate Water Needs}

Water consumption in the agricultural sector is about 7 billion cubic meters per year, which is about $70 \%$ of the total volume of water consumed nationally. The drinking water consumption of the population is estimated at 2.5 billion cubic meters per year.

\section{Future Water Needs}

Climate change, strong urban and demographic growth, and the nature of water resource management will exacerbate water stress. The demand for drinking water can easily exceed 4 billion cubic meter per year over the next few decades.

In agriculture, we have two possible scenarios:

\section{- The First Scenario:}

Represented by a slight change in the current management of water resources, an average increase in irrigated land and the maintenance of the current quality of agriculture, the demand for irrigation water will reach 15.4 billion $\mathrm{m}^{3}$

- The Second Scenario:

To improve the efficiency of water resources management, increase the irrigated area to 2,000,000 hectares and develop cereal and fodder crops, the demand for irrigation water will increase to 20 billion $\mathrm{m}^{3}$. 
In 1962, theoretical water availability per inhabitant per year was in the order of $1500 \mathrm{~m}^{3}$, in 1990 was $720 \mathrm{~m}^{3}, 680 \mathrm{~m}^{3}$ in $1995,630 \mathrm{~m}^{3}$ in $1998,500 \mathrm{~m}^{3}$ in 2009 , and it will be only $430 \mathrm{~m}^{3}$ in 2020 .

Algeria is one of the countries where water availability per capita is below the threshold set by the World Bank $\left(1000 \mathrm{~m}^{3} / \mathrm{hab} / \mathrm{an}\right)$. Water resources are estimated to 19 billion $\mathrm{m}^{3}$ (corresponding to about $600 \mathrm{~m}^{3} / \mathrm{hab} / \mathrm{an}$ ). The mobilization of water is facing the following problems:

- The spatial distribution of surface water resources requires substantial transfers to meet the needs of the less fitted regions; these facilities and operations of water mobilization are more and more expensive.

- The effectiveness of reservoir dams is reduced by the high evaporation affecting water bodies (reservoirs evaporate in Algeria from 1.3 to $2.2 \mathrm{~m} / \mathrm{year}$ and the problem of siltation ( 32 million $\mathrm{m}^{3} /$ year for 52 dams whose initial capacity is about 5.2 billion $\mathrm{m}^{3}$ ).

- The rate of loss in the networks of drinking water varies from $30 \%$ to $40 \%$.

In Algeria, the observed climate change across the globe has resulted in:

- An increase in the average, minimum, and maximum temperature recorded on all stations in northern Algeria since the 1970s and that continues to these days.

- On other records, the impacts of climate change have caused our country endemic drought since 1970, resulting in a worsening desertification with a degradation of more than $8 \%$ of the forest, wind, and water erosion of soil.

- A trend in rainfall during the past 25 years had a negative impact on water resources by:

- A rainfall deficit of about $30 \%$

- An impact on the level of filling of dams and groundwater recharge

- The impact on the socioeconomic structure

- An impact on the environment (desertification, urban pollution, industrial and agricultural, decline of groundwater levels and salinization of water result of the overexploitation of groundwater and drought)

\section{Impact of Climate Change on Superficial and Underground Water Resources}

Indeed, the 90 billion $\mathrm{m}^{3}$, which precipitate in average each year, only 12 billion $\mathrm{m}^{3}$ is surface water resources and two-thirds of this volume could be mobilized.

The decrease in rainfall creates a water deficit. It constitutes the most important factors to lead to reduce the flow of the seasons of winter and spring.

For example, lower liquid intake, on an annual scale, at the outlets of five basins in western Algeria (Fig. 7), varies from 16\% (Basin of Sidi Ali Ben Youb) to 55\% (chouly basins). At Bouhanifia dam, flows have registered a reduction of about $56 \%$ since 1979 date of change in the hydrological regime and $55 \%$ of reduction at Beni Bahdel dam since 1974 (Fig. 4). 

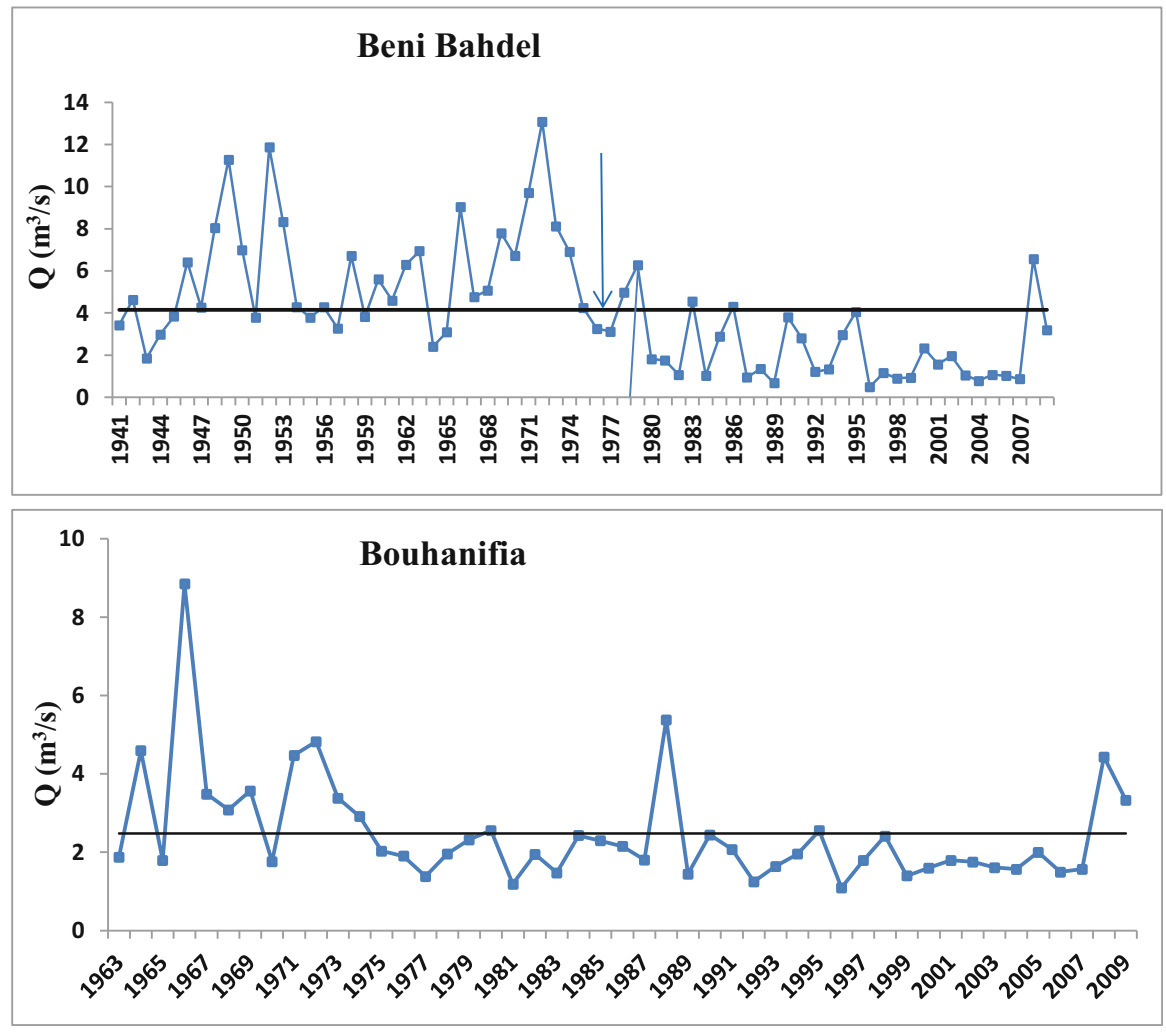

Fig. 4 Inflow to Beni Bahdel and Bouhanifia dams

At the level of the plain of Ghriss (west of Algeria) the exploited water varies from 72 to $88 \mathrm{hm}^{3}$ /year, while the natural recharge is about $64 \mathrm{hm}^{3} /$ year (Fig. 5). This decrease is mainly due to the lower rainfall in recent decades. This imbalance has led to a lowering of the groundwater from $5 \mathrm{~m}$ to $40 \mathrm{~m}$.

For the Chellif Basin, the total number of wells and drillings increased steadily from 5 in 1850 to 2080 in 2005 . This increase in the number of wells and drillings resulted in a change in the amount of mobilized water. These volumes were $3.75 \mathrm{Mm}^{3}$ in 1970 and $110.7 \mathrm{Mm}^{3}$ in 2005 in the high and medium chellif (Meddi and Boucefiane 2009).

\section{Future Projection}

The study of the temporal and spatial evolution of surface and underground water resources is considered as a major decision-making tool for the socioeconomic development of the Maghreb countries.

Dams are filled mainly by the few floods recorded during the rainy season. The recharge of the aquifers is ensured by infiltrations which occur in winter and spring. This recharge has become insufficient since the mid-1970s following the decrease in 


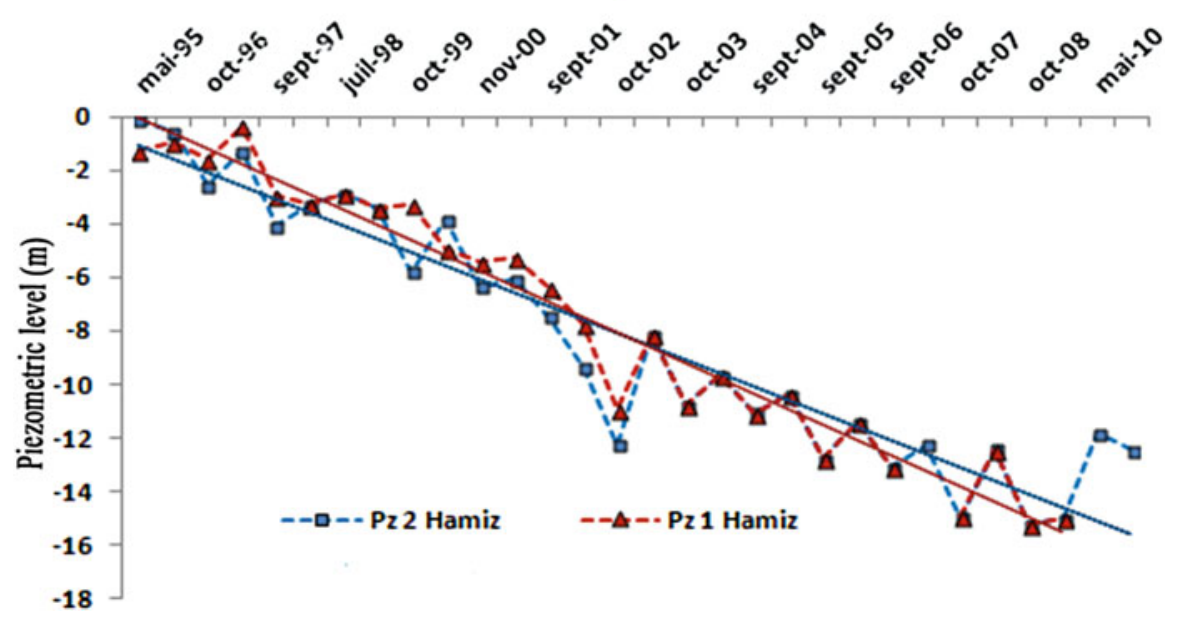

Fig. 5 Evolution of the piezometric level in Pz1 and Pz2 Hamiz, plain of Mitidja (1995 to 2011)

rainfall (Meddi and Hubert 2003; Hallouz et al. 2013; Zeroual et al. 2017) and the overexploitation of groundwater to meet irrigation water and drinking water needs. The drop in piezometric levels reached $40 \mathrm{~m}$ for the Mitidja Plain (Demmak 2008).

Climate projections will make it possible to establish scenarios for the availability of water resources at future horizons. Projections of the spatio-temporal variability of precipitation and temperature for the periods 2006-2060 and 2045-2100 performed by Zeroual (2017) using the RCA4 model (NorESM1-M), scenarios RCP4.5 and RCP8.5, for the periods 2006-2060 and 2045-2100 showed a stabilization of average rainfall compared to the period from 1951 to 2005 in eastern and southern Algeria and a decrease in the western part of Algeria (Figs. 6 and 7). This decrease will change from RCP4.5 to RCP8.5 and from 2006-2060 to 2045-2100. The climate models predict a decrease in precipitation and an increase in temperatures both on annual and monthly scales for the periods 2006-2060 and 2045-2100 (Zeroual 2017).

The impact on the flows will be very important as shown by Kahlerras et al. (2018) in a work on the Mazafran Basin (Fig. 8), in the center of Algeria. The Oued Mazafran, which drains a basin of $280 \mathrm{~km}^{2}$, for the RC4.5 scenario, will record a decrease in flows will be of the order of $29 \%$ in 2033 to reach a volume of 134.01 $\mathrm{Mm}^{3}$ compared to the reference period (1998-2014) which recorded an average volume of $189.85 \mathrm{Mm}^{3}$. For scenario RC8.5, a decrease will be of the order of $31.6 \%$ in 2028 with a volume of $129.8 \mathrm{Mm}^{3}$, by 2040 , the volume will be of the order of $129.9 \mathrm{Mm}^{3}$. These 2 years will be the least rainy with $178.4 \mathrm{~mm} /$ year and $184.8 \mathrm{~mm} /$ year, respectively (Kahlerras et al. 2018).

Kahlerras et al. (2018) have shown that the demand for water for the Mazafran Basin, whose population is estimated at about 615,956 inhabitants in 1998 and will be of the order of $1,724,880$ inhabitants by 2050 , there will be a recovery of demand 


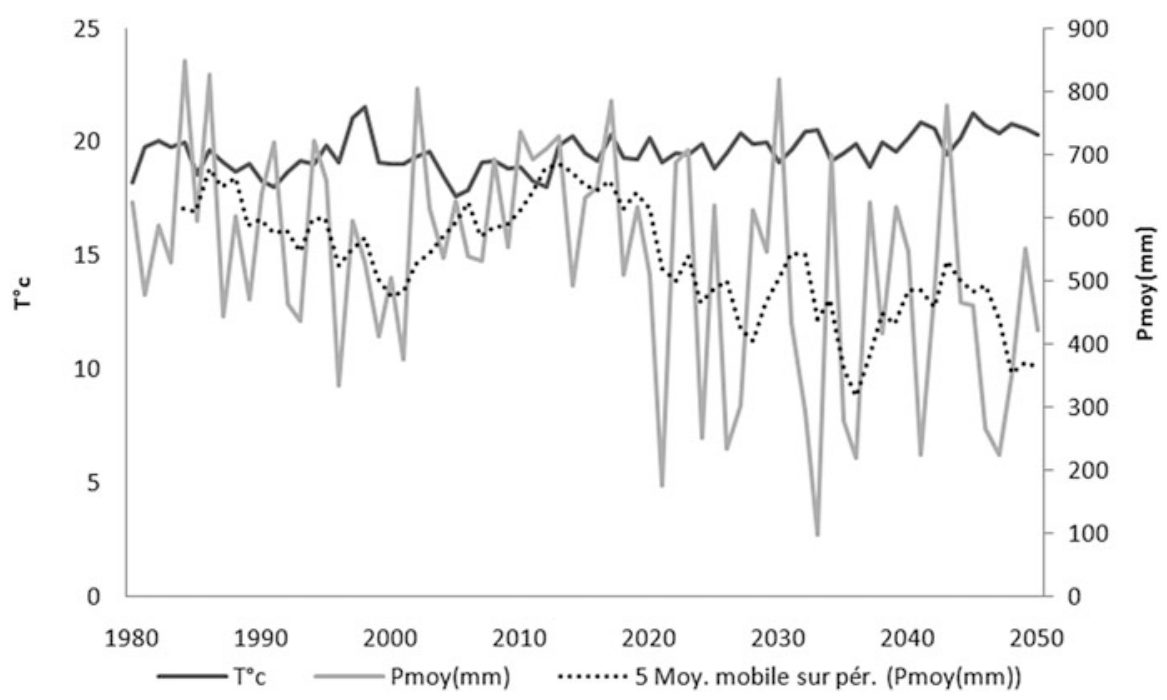

Fig. 6 Projected temperature and rainfall trend change at the time horizon of 2050 (scenario RC4.5) at the Mitidja plain (Kahlerras et al. 2018)

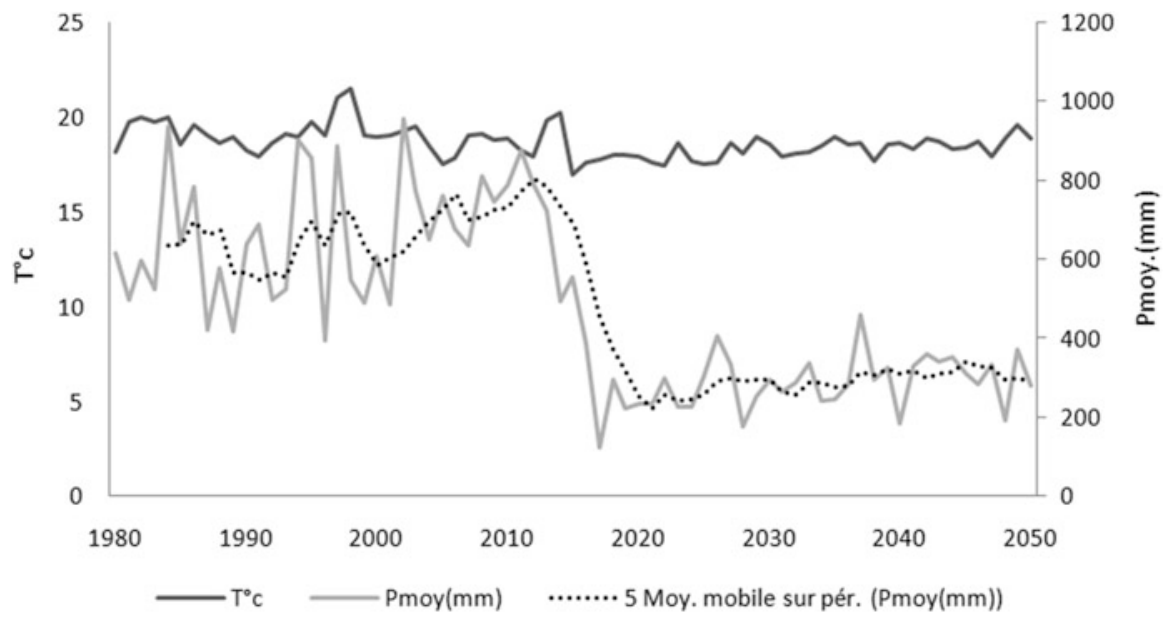

Fig. 7 Projected temperature and rainfall trend change at the time horizon of 2050 (scenario RC8.5) at the Mitidja plain (Kahlerras et al. 2018)

until 2040, the deficit after this date will be of the order of $3.44 \mathrm{Mm}^{3}$ in 2045 and will reach $95.3 \mathrm{Mm}^{3}$ in 2050 for scenario RC4.5 (Fig. 9). The situation will be more critical for the pessimistic scenario ( $\mathrm{RC} 8.5)$ where the rupture between supply and demand will be recorded as early as 2025 . The deficit will be of the order of $56.65 \mathrm{Mm}^{3}$ in 2030 and will reach $130.95 \mathrm{Mm}^{3}$ in 2050 (Fig. 10). 


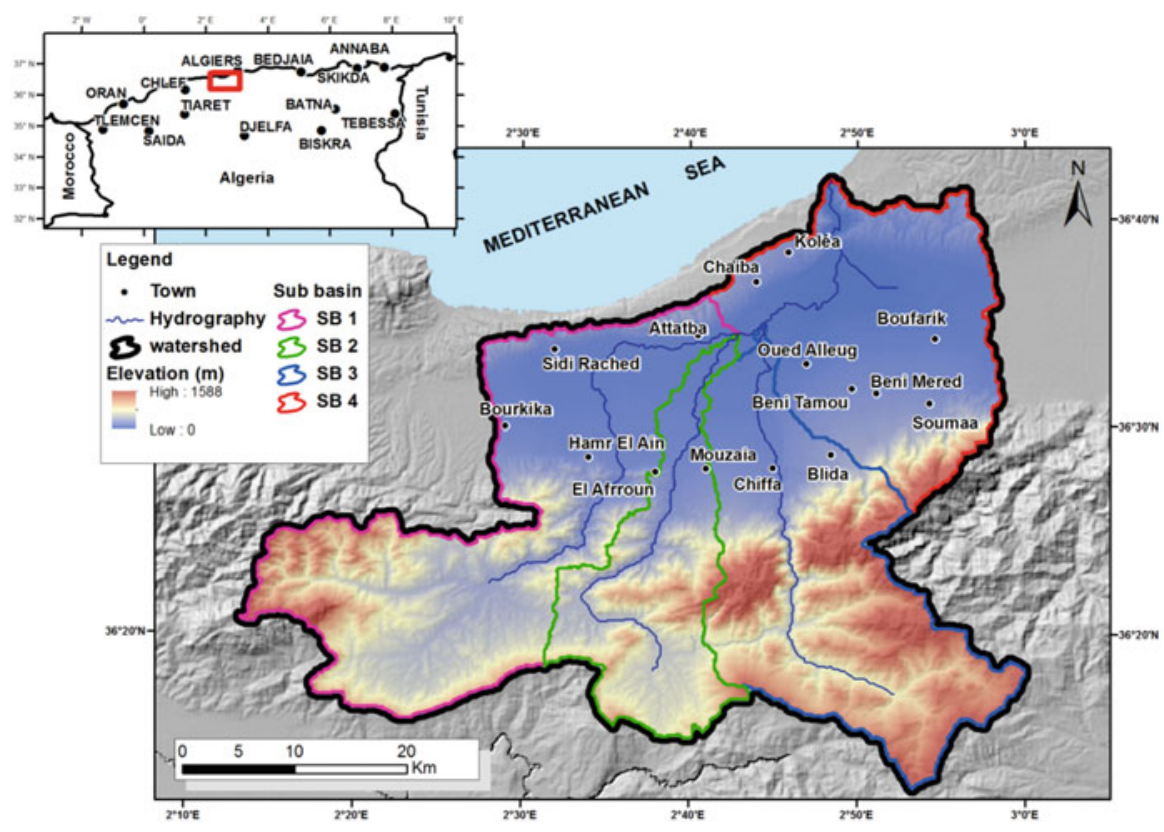

Fig. 8 Geographical situation of the Mazafran watershed (Kahlerras et al. 2018)

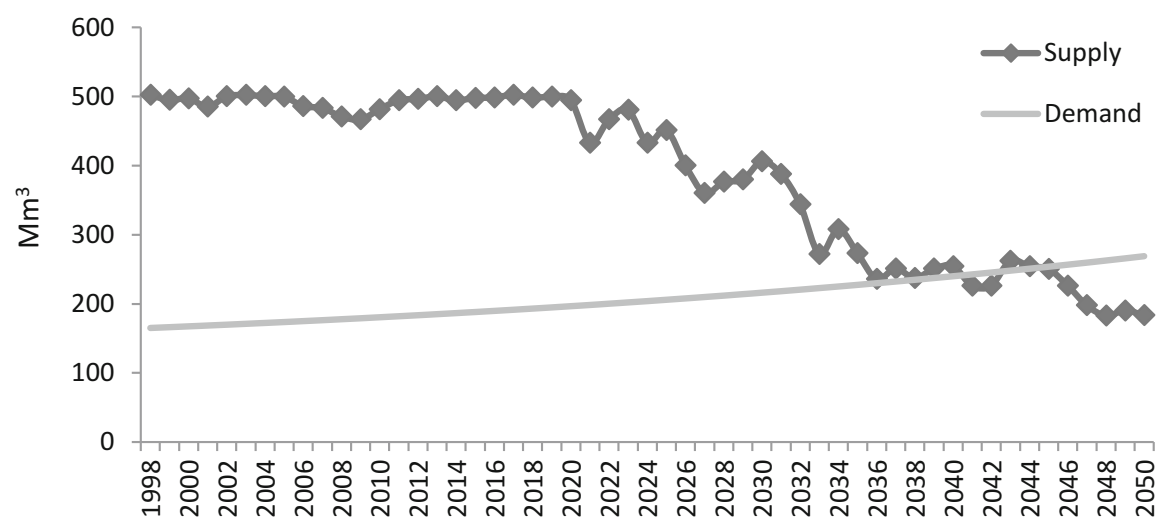

Fig. 9 Assessment of water resources management for the RC 4.5 scenario (Kahlerras et al. 2018)

For basins located in western Algeria, the region most affected by the reduction in rainfall by $25 \%$ (Meddi and Hubert 2003), winter flows will show a clear downward trend, mainly due to the decrease in rainfall and the increase in PET for the two scenarios RCP8.5 and RCP4.5. On the other hand, spring flows will increase according to RCP 8.5 and decrease according to RCP 4.5. In terms of observed differences, the RCP 8.5 scenario forecasts a decrease in winter flows of about $33 \%$ on average in all the studied basins by $2039,31 \%$ by 2069 , and $50 \%$ by the end of 


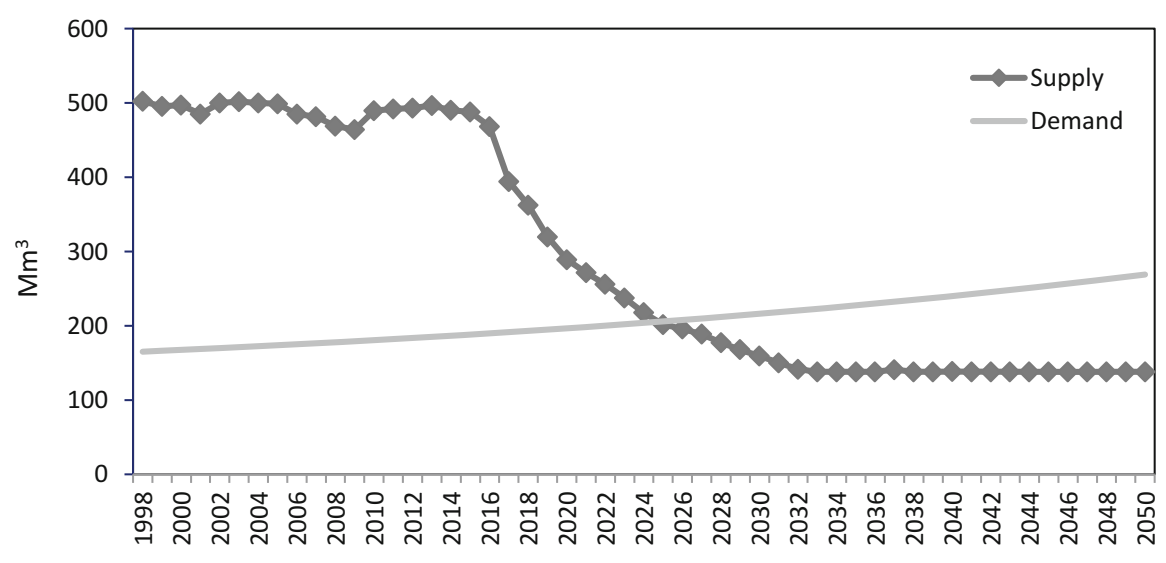

Fig. 10 Assessment of water resources management for the RC 8.5 scenario (Kahlerras et al. 2018)

the twenty-first century. The RCP4.5 scenario predicts a decrease of about 50 to $60 \%$ for all horizons. In addition, the decrease is estimated at $80 \%$ for spring flows according to the RCP4.5 scenario. In contrast, the RCP8.5 scenario forecasts a $25 \%$ increase for the same season (Haddour et al. 2019).

\section{Palliative Measurements}

To cope with the change in rainfall reduction, Algeria has undertaken a major program based on large transfers and the use of the non-convent water.

The state has made a considerable effort to increase the connection rate, mainly in rural areas. This rate increased from $44 \%$ for some rural regions to more than $60 \%$ (http://www.mre.gov.dz). The recent decision to use non-conventional water, desalination, will provide a substantial addition to alleviating the suffering of populations of large cities and rural areas. An emergency program was decided by the government for commissioning 21 desalination stations with a total capacity of $57,500 \mathrm{~m}^{3} /$ day (http:// www.mre.gov.dz). For this project, the Government aims to strengthen the water supply of some urban areas situated in the coasts in the summer season. Water dams originally planned for these towns will be transferred to the interior cities. This procedure will develop these towns and villages that are in poverty and enable people to develop agriculture and prevent diseases inherent to the lack of water (http://www.mre.gov.dz).

During the warm season, the deficit is growing due to the increasing demand and declining reserves of conventional water (http://www.mre.gov.dz). However, these programs cannot alone solve the water problem in the long term. Rigorous management and increased storage capacities of surface and groundwater are essential to meet the demand. The reuse of wastewater, especially in aquifer recharge and irrigation, will increase, with no doubt, the water resource available in the medium and long term (http://www.mre.gov.dz).

There is a considerable waste in agriculture. To remedy to this, it is necessary to restructure the peasants in unions capable to organize the operation of irrigation and to modernize, as appropriate, irrigation techniques. 
For a better management, decentralization of the management of water supply and sanitation in order to promote the emergence of effective management by elected authorities and representative committees of citizens. We must encourage and facilitate management by major river basins (basin agencies).

Once the impacts on water resources will be determined for the main socioeconomic activities, strategies to adapt to the negative impacts of these climate change scenarios for Algeria can be developed for the benefit of policy makers. They will be able to draw a proper water policy in the medium and long term.

\section{Large Transfers}

To cope with water shortages in certain parts of the country, the government has started the constructions of several large transfers across the country, we give as examples:

- Beni Haroun Development in the east of the country: 242 million $\mathrm{m}^{3}$ will be used to supply drinking water for 4.62 million inhabitants of several department: Jijel, Mila, Oum El Bouaghi, Batna, Constantine, Ain M'lila, and Khenchela. Also, 262 million $\mathrm{m}^{3}$ for irrigation of 30,000 hectares.

- Mobilization of water resources in Algiers: This project consists of projects set to ensure an annual volume of 595 million $\mathrm{m}^{3}$. A total of $435 \mathrm{million}^{3} /$ year for drinking water supply for 7.95 million inhabitants and 160 million $\mathrm{m}^{3}$ for the irrigation of about 30,000 ha.

- Mobilization of water resources in western Algeria: The development of the water production of Chellif-Kerrada called MAO provides 155 million $\mathrm{m}^{3} /$ year for the drinking water in the corridor Mostaganem-Arzew-Oran.

\section{Desalination of Seawater}

A very ambitious program was initiated to meet the water demand constantly increasing through desalination of sea water. This resource is inexhaustible and can be exhausted on a coast of $1200 \mathrm{~km}$. In addition, the population and the industries that are large consumers of water are near the sea to defend this approach. The field of desalination of seawater has in recent years a remarkable technological step through the development of different processes. The program is composed of large monoblock stations and a desalination plant. For the first category, 21 stations with a total capacity of $57,500 \mathrm{~m}^{3} /$ day:

- $13,000 \mathrm{~m}^{3} /$ day for the western region.

- $22,500 \mathrm{~m}^{3} /$ day for the central region

- $7000 \mathrm{~m}^{3} /$ day for the east region

For the large stations, the regional distribution is made as follows: western region (1.29 million $\mathrm{m}^{3} /$ day $)$, the central region $\left(0.45\right.$ million $\mathrm{m}^{3} /$ day $)$, and the eastern region $\left(0.15\right.$ million $\mathrm{m}^{3} /$ day $)$. 


\section{Recommendations}

- Algeria will build more than 40 dams to reach 130 dams by 2030 to increase the mobilized water resources.

- Reduce leakage from urban and rural drinking water systems by $30 \%$ to $20 \%$ by 2030.

- Save between $20 \%$ and $25 \%$ of water intended for irrigation by 2030 .

- Economy of $20 \%\left(1.4\right.$ billion $\left.\mathrm{m}^{3}\right)$ in agriculture could provide drinking water to half of the Algerian population

- The used water treatment stations can process up to one billion $\mathrm{m}^{3}$ in the future. This unconventional water resource is an excellent addition to irrigation and can easily cover more than 100,000 hectares.

- Integrated Water Resources Management (IWRM) is a good solution for smart and optimal management through the development of scenarios to counter the impacts of future climate change.

- Develop integrated management of water resources by basin.

- The development of research projects to be conducted by a consortium of farmers and research laboratories to develop optimized complete solutions for the reuse of treated water in irrigation.

\section{Morocco}

\section{Water Potential and Climate Change}

Morocco has a potential of water estimated at 22 billion $\mathrm{m}^{3}, 18$ billion $\mathrm{m}^{3}$ of surface water, and 4 billion $\mathrm{m}^{3}$ of groundwater (Choukr-Allah 2011). Morocco counted 135 large dams with a total capacity of 17,500 million $\mathrm{m}^{3}$ in 2009, as well as about 100 small dams with a capacity of 100 million $\mathrm{m}^{3}$ for local needs in drinking water, irrigation, and livestock, and there are also 13 systems for transferring water between watersheds (https://water.fanack.com/morocco/water-infrastructure-in-morocco/). The national water strategy foresees the construction of about 60 large dams by 2030 , with a total capacity of about 7 million $\mathrm{m}^{3}$ plus 1000 small dams for local development (Alaoui 2013). The water resources reduce in particular because of overexploitation (Fig. 11). This depletion will increase with the advent of climate change. Similarly, the development of industrialization and intensification of agriculture water consumption would cause further degradation of groundwater.

In addition, water resources will be subject to further exploitation, the domestic and industrial wastewater will constitute a problem concern threatening the human health and the environment. Thus, the urban wastewater was about $600 \mathrm{Mm}^{3} /$ year in 2015 , it will increase to about $750 \mathrm{Mm}^{3} /$ year in 2030 and $900 \mathrm{Mm}^{3} /$ year by 2050 (World Bank Group 2017b).

The recorded rainfall shows a negative national trend (Fig. 12). The spring rains have fallen over $40 \%$ since the $1960 \mathrm{~s}$. The drought seems to become more persistent over time. The temperature has increased as shown by the Fig. 13. The dry maximum length is rising during the rainy season, significantly during the end of this season (February to April) where it increased 15 days since the 1960s. At the same time, the 


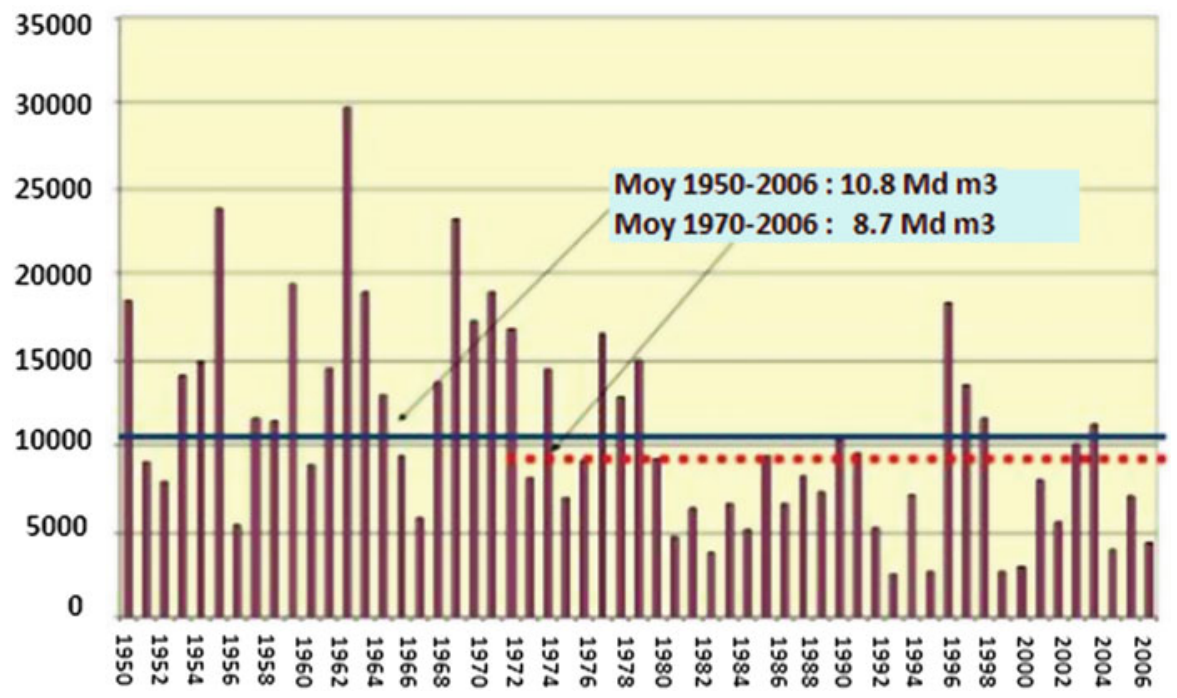

Fig. 11 Evolution of the water contributions in dams of Morocco (Ben Abdelfadel and Driouech 2008)

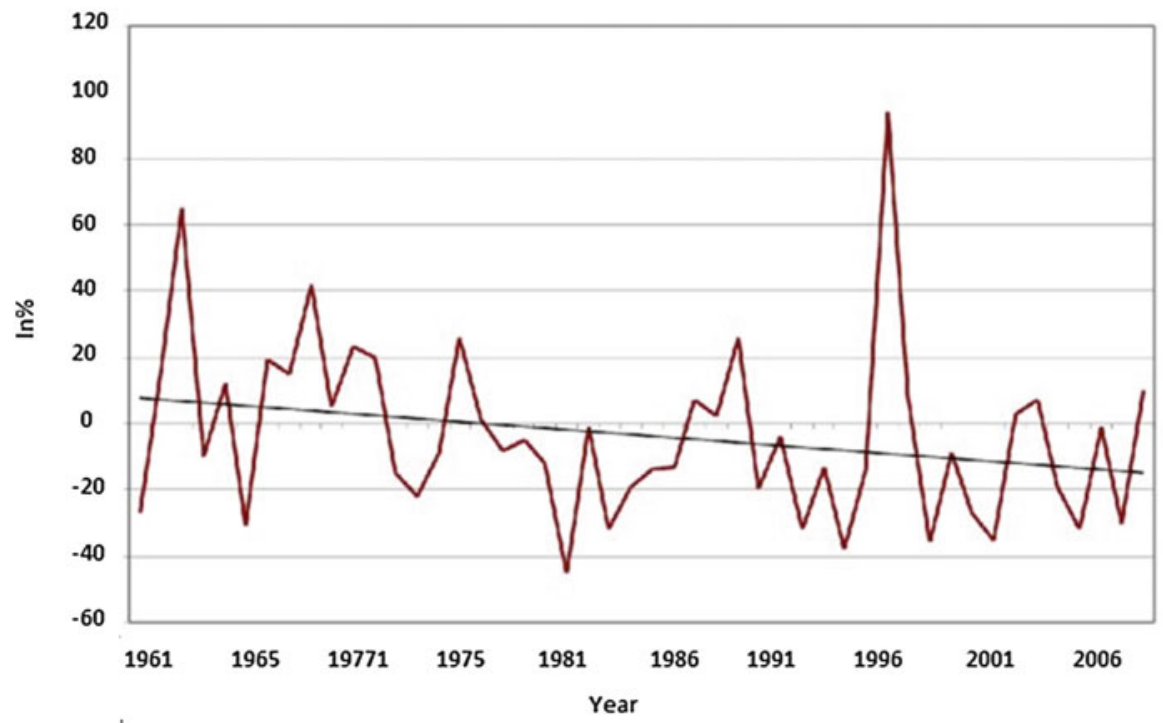

Fig. 12 National averages (\%), defects of the cumulative rainfall totals annual, calculated on the 14 meteorological stations in Morocco (1961-2008), Driouech (2010)

total number of rainy days shows a negative trend and indicates an increase in the annual number of dry days. Many regions have become drier between 1961-1985 and 1986-2005 (Ben Abdelfadel and Driouech 2008). 


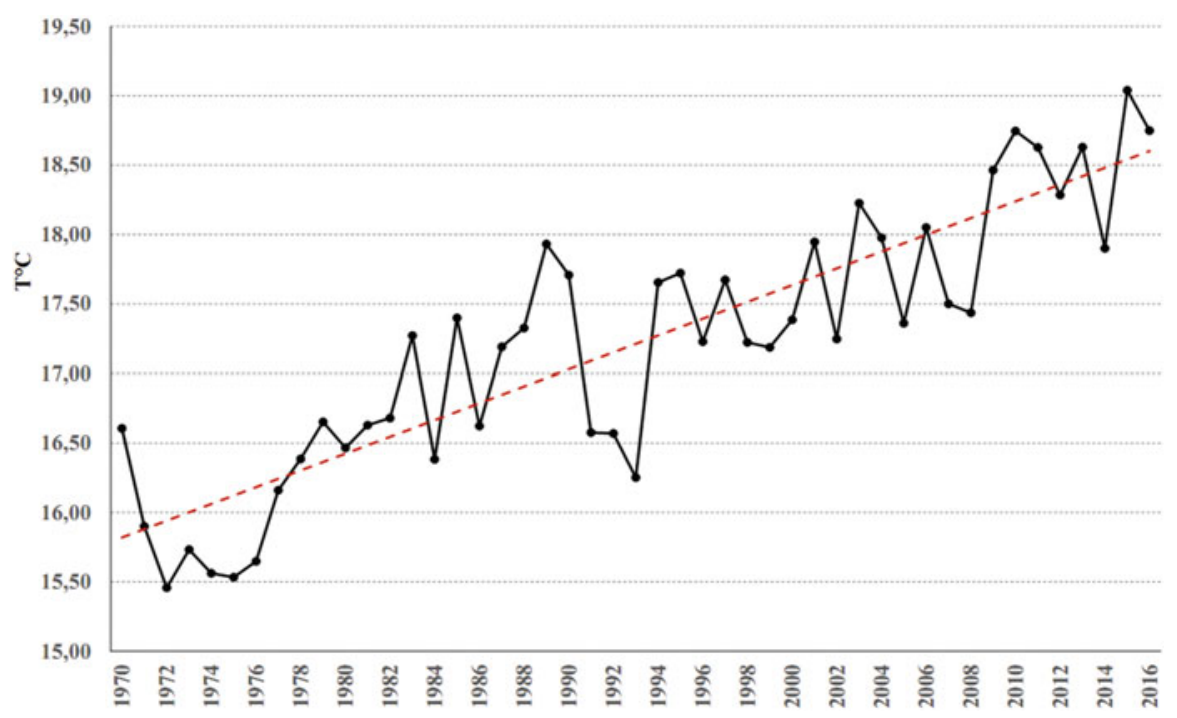

Fig. 13 Average annual temperatures at the Oujda station in Morocco (El Hafid et al. 2017)

The drought has led the agricultural sector in Morocco, for example, to limit the not needed annual crops, to the prohibition of any new tree planting and to the prohibition of vegetable crops in dry years from 1981 to 1982.

The potential of renewable water resources is estimated at 22 billion $\mathrm{m}^{3}$ per year of which 18 billion $\mathrm{m}^{3}$ of surface water. From the available potential two-thirds are currently mobilized and used up to $88 \%$ in irrigation and $12 \%$ in the drinking water.

Morocco's Third National Communication on Climate Change 2016 has shown that, according to observed climate trends and long-term projections, climate change is already underway based on the climate trends observed between 1960 and 2005 (MDCE 2016). Average annual temperatures have increased from 1.0 to over $1.8{ }^{\circ} \mathrm{C}$ (MDCE 2016). Precipitation has declined between 3\% and $30 \%$ with a $26 \%$ decline in the northwestern region of Morocco (MDCE 2016). On average, warming varied between 1 and $3{ }^{\circ} \mathrm{C}$ depending on the region during the period 1998-2007 compared to 1971-1980 (MDCE 2016).

\section{Surface Water}

According to the second submission, river flows have recorded a $20 \%$ reduction since 1950 (SCNCCRM 2009). Knowing that the surface water resources on the whole territory are evaluated in average year to 18 billion $\mathrm{m}^{3}$, varying, according to the years, from 5 to 50 billion $\mathrm{m}^{3}$. More than $51 \%$ of the surface water resources are produced at the level of four hydrographic basins (Loukkos, Tangier, Mediterranean Coastal, and Sebou) (SCNCCRM 2009).

The last four decades have seen a marked decrease in stream flows and natural recharge of groundwater (Sinan and Belhouji 2016). The decreases in superficial 


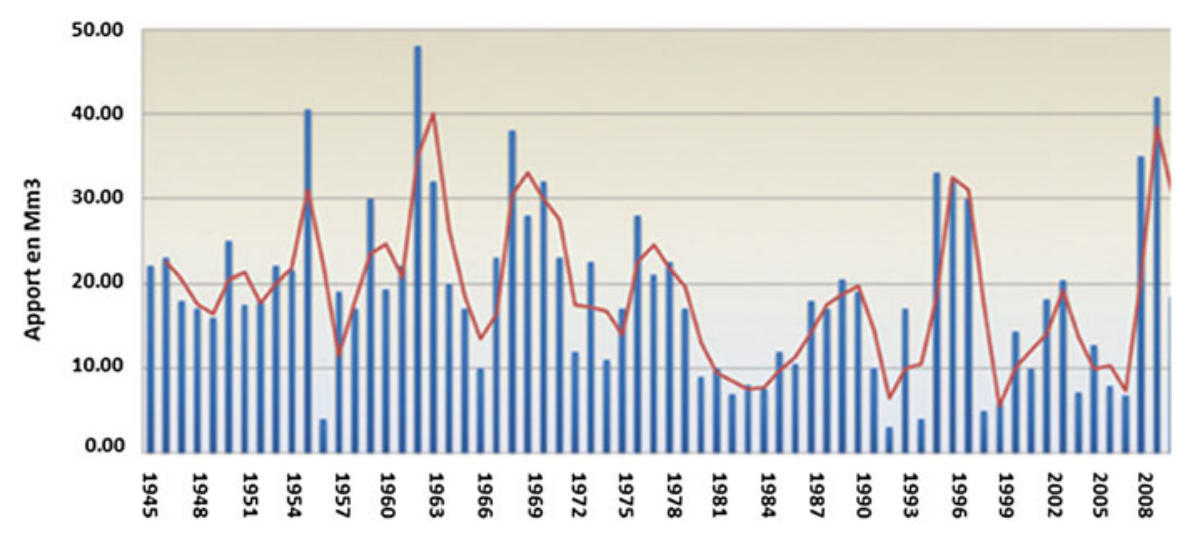

Fig. 14 History of surface water supplies in Morocco 1945-2010 (MDCE 2014 in Sinan and Belhouji 2016)

flows reached nearly $20 \%$ between $1970-2006$ and $1950-2006$ and exceed $70 \%$ in certain regions of Morocco (Sinan and Belhouji 2016), Fig. 14.

To show the probable effects of climate change on surface water resources, two basins feeding the dams of Hassan Addakhil (located on Wadi Ziz in the south-east) and Idris I (located on Wadi Innaouene, tributary of the oued Sebou, central Morocco) are considered. In Morocco, like other countries around the Mediterranean, surface water flows depend mainly on rainfall.

Figs. 15 and 16 present the history of water inflow in the Hassan Addakhil (by Wadi Ziz) and Idriss I (by Wadi Inaouene, Basin of Sebou) dams over the period 1950-2002 (Sinan et al. 2009; Sinan and Belhouji 2016; MDCE 2016). They show a clear downward trend in these inputs, especially since the beginning of the 1980s (more than 30 years ago), a clear consequence of the negative effects of climate change. The average water inflow during this period (1950-2002) was respectively $122 \mathrm{Mm}^{3} /$ year and $516 \mathrm{Mm}^{3} /$ year for the Hassan Addakhil and Idriss I dams (Sinan et al. 2009; Sinan and Belhouji 2016).

The water resources of the two basins will record decreases as below compared to the end of the twentieth century (Sinan and Belhouji 2016):

- 2020: $-7.6 \%$ (optimistic scenario) and $-8.6 \%$ (pessimistic scenario)

- 2050: $-2.3 \%$ (optimistic scenario) and $-12.8 \%$ (pessimistic scenario)

- 2080: $-7.6 \%$ (optimistic scenario) and $-40.6 \%$ (pessimistic scenario)

\section{Groundwater}

Groundwater represents about $20 \%$ of the potential of Morocco's water resources. These waters are of great importance for the socioeconomic development of the Kingdom. Morocco has 96 aquifers, 21 of which are deep and 75 shallow and cover a total area of $80,000 \mathrm{~km}^{2}$. The level of these aquifers shows a continuous decrease due to drought, reduction of natural recharge, and overexploitation. This reduction in groundwater level is about $2 \mathrm{~m}$ each year. The volume of groundwater withdrawn 


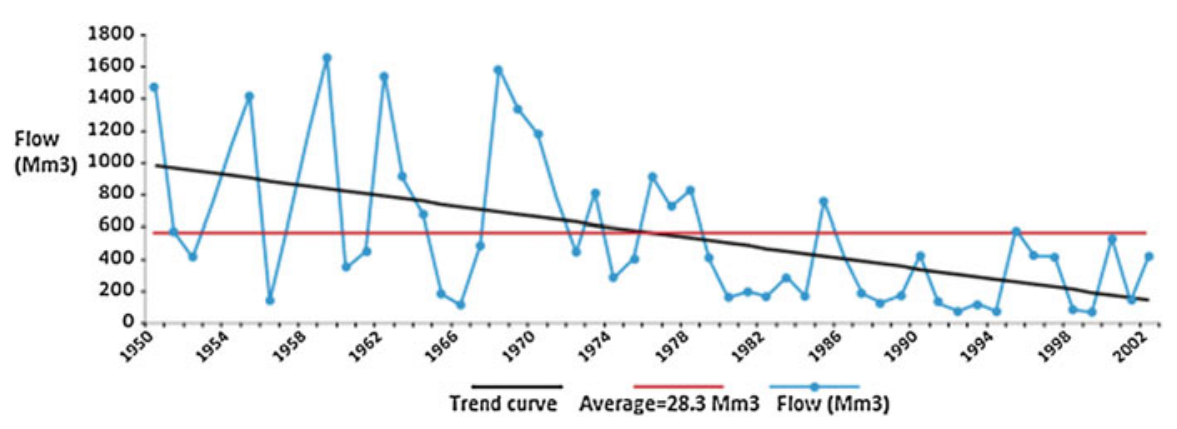

Fig. 15 Historical water inflow in Hassan Addakhil Dam by Wadi Ziz (Sinan et al. 2009)

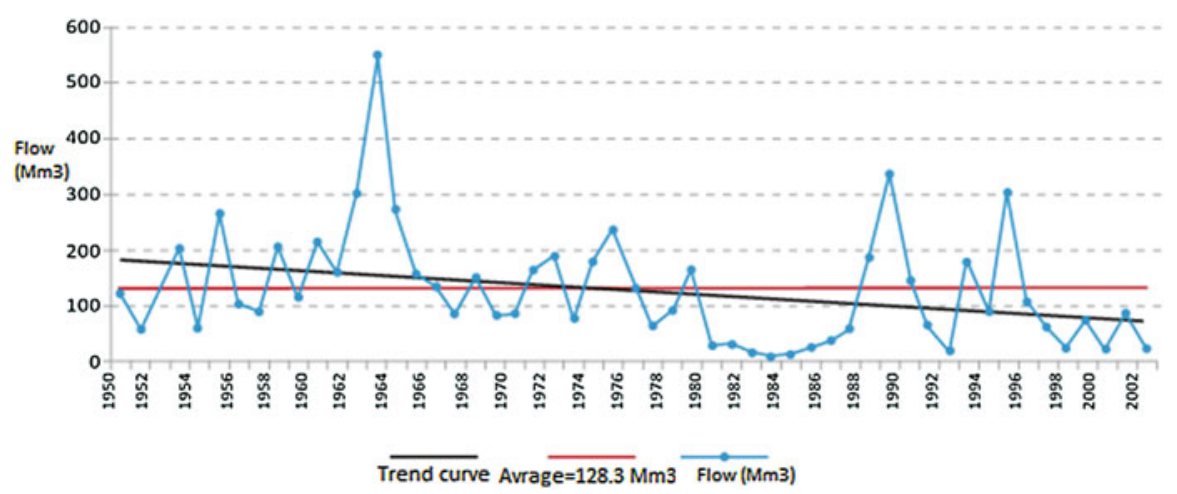

Fig. 16 History of water supplies in the Idriss I dam by the Inaouene wadi - Sebou basin (Sinan et al. 2009)

from the aquifers exceeds the renewable water resources. In fact, recent estimates estimate withdrawals at 5 billion $\mathrm{m}^{3} /$ year, which is a reflection of the nonrenewable potential of groundwater with an average volume of 1 billion $\mathrm{m}^{3} / y$ ear. This overexploitation has led to a general decline in groundwater levels sometimes exceeding $2 \mathrm{~m} /$ year in some aquifers (Sinan and Belhouji 2016).

The impact of reduced rainfall and consequently the groundwater recharge, as well as the overexploitation of groundwater has led to the lowering of the piezometric level. According to Amraoui (2019), between 1980 and 2017, the deep aquifer of Saiss plain at the level of the piezometer 290/22, controlling the region of Meknes, shows an average decrease of $3 \mathrm{~m} / \mathrm{year}$ (Fig. 17). Groundwater exploitation in this area increased from 4 million $\mathrm{m}^{3}$ in 2005 to almost $10 \mathrm{Mm}$ in 2014 (Ameur 2017). For this aquifer, the Sebou Watershed Agency (ABHS) has identified more than 9000 water points exploiting the water table, most of which are not authorized (Amraoui 2019). This is the equivalent of 4 holes per $\mathrm{Km}^{2}$ (Amraoui 2019). In terms of use, agriculture would take 225 million $\mathrm{m}^{3}$ annually and 100 million $\mathrm{m}^{3}$ of drinking water (Amraoui 2019). 


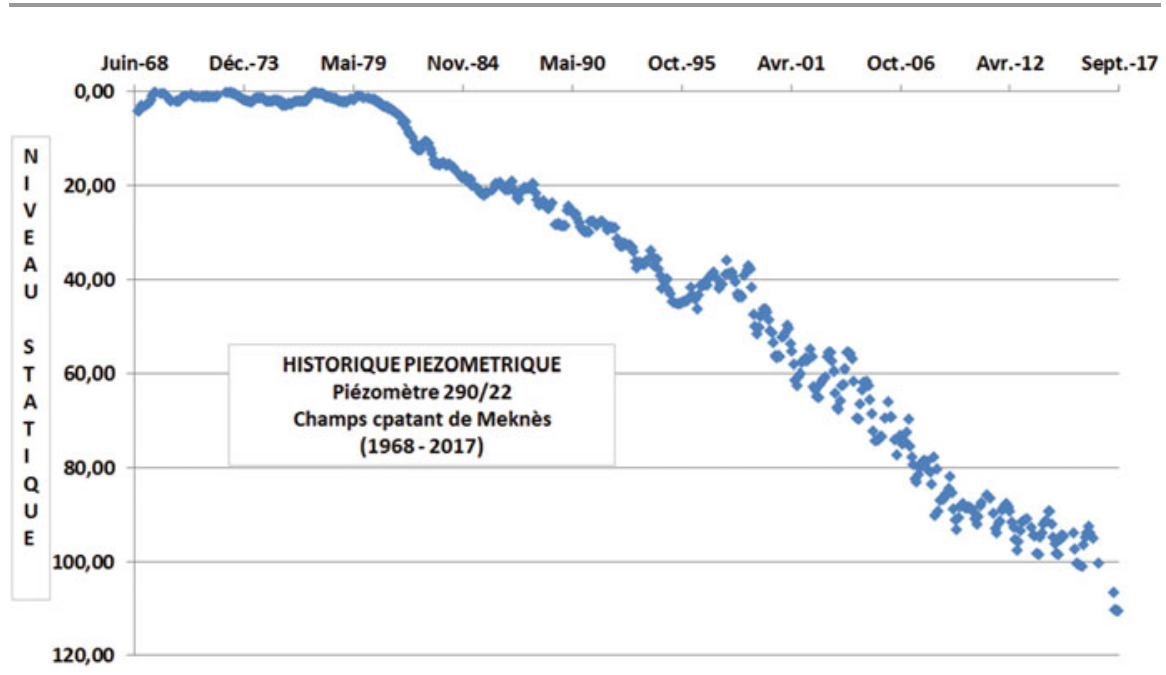

Fig. 17 Decrease of the level of aquifer of Siass plain, Morocco (Amraoui 2019)

The impact of climate change and reduction of water resources have led to:

- Worsening of water supply in rural areas

- Very important economic impact on the agricultural sector: drop in grain production, irrigation water deficit, increased unemployment in rural areas

- The impact on water quality

\section{Future Projections}

Projections of climate to future horizons indicate a negative trend of annual rainfall that varies between 10 and $20 \%$ to reach $30 \%$ in Saharan regions by 2100 . The trend in annual average temperatures show an increase of 0.5 to $1^{\circ} \mathrm{C}$ in 2020 and 1 to $1.5^{\circ}$ $\mathrm{C}$ in the 2050 and 2080 horizons across the country (MDCE 2016; Sinan and Belhouji 2016). The observed temperature has increased by $0.5{ }^{\circ} \mathrm{C}$ each decade since 1970. It is above the world average of about $0.15{ }^{\circ} \mathrm{C}$ (World Bank Group, 2017). The forecasts show that Morocco will reach 3 to $7^{\circ} \mathrm{C}$ from here at 2100 , with 4 to $7{ }^{\circ} \mathrm{C}$ for the summer months (June, July, and August). Annual rainfall is expected to decrease by 10 to $40 \%$, especially by 10 to $30 \%$ during the rainy season from October to April and by 10 to $40 \%$ during the dry season from May to September (World Bank Group 2017a).

The water potential in Morocco is estimated at 22 billion cubic meters per year. With a forecast to 38 million inhabitants in 2030 and despite a considerable effort, in terms of construction of hydraulic structures and access to unconventional resources, this quantity of water could fall to $500 \mathrm{~m}^{3}$ by 2030 under the pressure of climate change, population growth, and pollution increase in economic activity (INDC 2015). Over the next 20 years, Morocco will be more vulnerable to drought and other extreme weather events (World Bank Group 2017b). 
These projections also show that the water/year/inhabitant capital would be significantly reduced by 2050 and 2080, thus creating a situation of water scarcity (water capital/year/inhabitant of less than $500 \mathrm{~m}^{3} /$ year/inhabitant) between the 2030 and 2050 horizons for all considered socioeconomic scenarios (Sinan and Belhouji 2016; MDCE 2016), Table 1 and Fig. 18.

\section{Palliative Measurements}

The adaptation is a process allowing improving, developing, and implementing strategies to mitigate the consequences of climatic events, to cope and to take advantage.

- Participatory approach: associate all communities and socio-professional categories capable to suffer the consequences of climate change

- Proactive approach: situations of crisis, so far as it is possible

- Optics of sustainable development

- Adaptation of infrastructure

- Use of nonconventional water resources

Currently, Morocco has 144 large dams and 13 others under construction. As part of a National Water Plan by 2030 and to meet the water needs of the population to avoid an imbalance between demand and supply by 2030, Morocco will realize close

Table 1 Projection of capita $\mathrm{m}^{3} /$ inhabitant/year (Sinan and Belhouji 2016)

\begin{tabular}{l|l|l}
\hline Year & Optimistic scenario & Pessimistic scenario \\
\hline 1960 & 2560 & 2560 \\
\hline 2000 & 775 & 775 \\
\hline 2020 & 575 & 569 \\
\hline 2050 & 518 & 464 \\
\hline 2080 & 342 & 217 \\
\hline
\end{tabular}

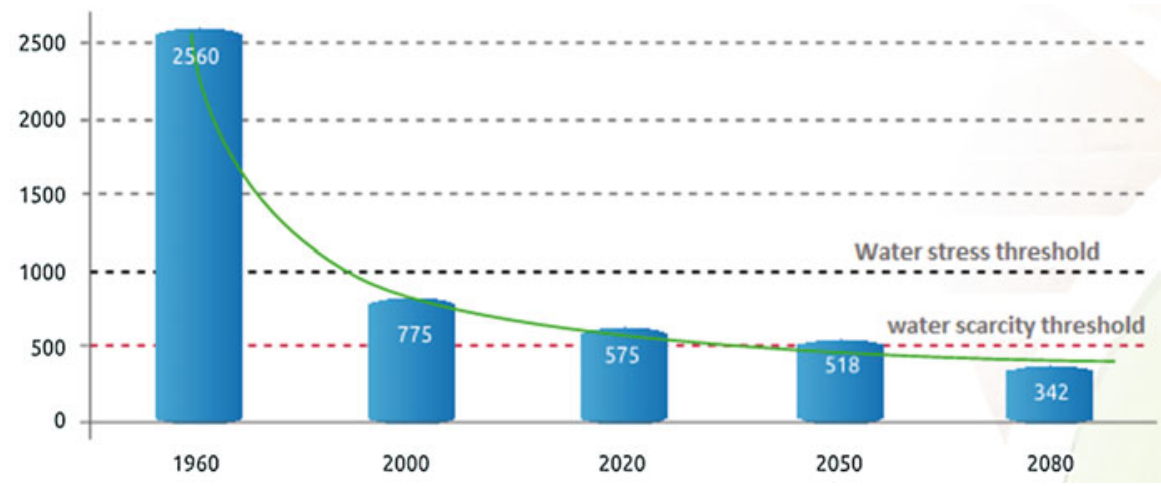

Fig. 18 Water capital projection $\left(\mathrm{m}^{3} /\right.$ inhabitant /year) optimistic scenario (Sinan and Belhouji 2016) 
to 1000 small dams and dams in different regions of Morocco between 2019 and 2026 (Plan National de l'Eau, horizon 2030).

\section{Nonconventional Water Resources}

(a) Reuse of Treated Wastewater:

According to the national water plan for 2030 , the potential of waters that can be reused by 2030 is around 325 million $\mathrm{m}^{3} /$ year. This volume constitutes the potential of the usable water. To achieve these objectives, Morocco plans to carry out 162 projects in the watersheds of: Loukkos, Moulouya, Sebou, Bou Regreg Chaouia, Oum Er Rabiî, Tensift, Souss Massa Drâa, Guir Ziz Rhéris, and Sakia El Amra Oued Eddahab.

(b) Desalination

Desalination of seawater is an alternative For Morocco. Morocco is using since 1990 the desalination of seawater including the establishment of a station in 1995 . This unit has a production capacity of $7000 \mathrm{~m}^{3} /$ day of drinking water. In order to develop this sector, the government implements in Agadir another desalination station of $80,000 \mathrm{~m}^{3} /$ day, which should be operational in 2010 . In addition, in view of saving water, the study suggests to "fight against failures in water networks and water distribution, to raise awareness on water scarcity and promote the use of plants resistant to water stress." Because, the study conducted by the High Commissioner for Planning shows that Morocco loses 1.3 billion per year including 1.1 billion $\mathrm{m}^{3}$ in agriculture and 200 million $\mathrm{m}^{3}$ in the drinking water and industrial sector.

A seawater desalination plant will be built in the Agadir region. It will be powered by solar energy, so it is a $100 \%$ ecological process in terms of renewable energy. Ultimately, it plans to produce about 275,000 cubic meters of water per day, of which 150,000 will be dedicated to human use and 125,000 to be used for irrigation of the 13,600 hectares of plantations in the southwest of the Kingdom, the maximum production capacity being $450,000 \mathrm{~m}^{3}$ per day.

\section{Recommendations}

According to the national water plan for 2030 of Kingdom of Morocco and to ensure the balance between supply and demand, the following operations will be carried out:

- The increase to $80 \%$ of the national average of the efficiency of drinking water distribution networks by 2025 .

- The maintenance of the same level until the year 2030 and the search and repair of leaks, which will reduce the demand for drinking water by about 120 million $\mathrm{m}^{3}$ per year by 2025 .

- Saving water in irrigation by transforming traditional irrigation systems to local irrigation system (drip system) at a rate of 50,000 ha per year and saving 4.1 
billion $\mathrm{m}^{3}$ by 2020, and as part of the Green Morocco plan, efforts will be made to save an additional 3.2 billion $\mathrm{m}^{3}$ by 2030 .

- The construction of fourteen dams in progress, a further 35 are planned, in addition to the use of non-traditional water resources, such as the desalination of seawater at a rate of 510 million $\mathrm{m}^{3}$ and the reuse of 325 million $\mathrm{m}^{3}$ of wastewater after purification (Plan national water supply by 2030)

- The World Bank (2017) indicates that $35 \%$ of potential water resources are wasted, which requires a new strategy to preserve this resource.

- The National Water Plan provides, to meet the demand for water by 2030, an investment of 220 billion DH by 2030, which will be used among others to the construction of 3 dams per year.

- Develop integrated management of water resources by basin.

\section{Tunisia}

\section{Water Potential and Climate Change}

Tunisia has about 4766 million $\mathrm{m}^{3}$ of exploitable resources for the year 2017, the equivalent of $450 \mathrm{~m}^{3} /$ year/inhabitant for all uses combined. The water mobilized in Tunisia is divided into surface waters (55\%) $2630 \mathrm{Mm}^{3}$ and groundwater (45\%) $2136 \mathrm{Mm}^{3}$. Also, it should be noted that $88 \%$ of groundwater has salinity greater than $3 \mathrm{~g} /$ liter (Lahacher and Pillet 2008). Water resources in Tunisia are distributed as follows: $80 \%$ for irrigation, $14 \%$ for water drinking, and $6 \%$ for industry and tourism (SIGMA 2017). Tunisia had 17 dams before 1990. It built 20 dams during the first ten-year plan between 1990 and 2000. Then, during the 2 nd ten-year plan from 2001 to 2011, Tunisia made 10 dams. The current total capacity of the 33 dams is $1.8 \mathrm{Mm}^{3}$ in 2018 according to the Ministry of Agriculture. The 253 collinear dams have a total capacity of $266 \mathrm{Mm}^{3}$ (Ouasli 2015). The 893 collinear lakes have a total capacity of $93 \mathrm{Mm}^{3}$. Groundwater is produced by 138,000 shallow wells and 5400 deep wells (SIGMA 2017). The mobilization of water resources is about $95 \%$ of available water resources (Ouasli 2015).

By studying the evolution of the contributions to the main dams over the period from 1947 to 2004, two main conclusions can be distinguished (TSNCUNFCCC 2013):

- The contributions decrease by $27 \%$ during the period from 1976 to 2004 compared to the period 1947 to 1975.

- Contributions at the level of the northern dams during the period from 1976 to 2004 , on the other hand, are $21 \%$ higher than the current average inputs.

Tunisia is located in the category of the least endowed countries with water resources in the Mediterranean. Indeed, for a population of 10 million inhabitants, the average allocation per capita per year is estimated at $450 \mathrm{~m}^{3}$. This figure will 
decrease gradually to $350 \mathrm{~m}^{3}$ per capita in 2030 for a population of 12 million inhabitants (Hamza 2007).

The surface water resources are highly variable in time and space. The average interannual surface water inflow is estimated at 2.7 billion $\mathrm{m}^{3}$ per year $(55.5 \%), 80 \%$ are from northern regions of Tunisia (Elloumi 2016). The groundwater resources are estimated, annual averages, about 2165 billion $\mathrm{m}^{3}$ (45.5\%) (Elloumi 2016). The volume of water mobilized in 2015 reached $4.6 \mathrm{~mm}$ (98\%) (Elloumi 2016).

The increase in temperatures would vary between 0.8 and $1.3{ }^{\circ} \mathrm{C}$ in 2020 and $2.1{ }^{\circ} \mathrm{C}$ in 2050 with the decrease of rainfall by 10 to $30 \%$, the loss of $28 \%$ of conventional water resources, and $20 \%$ of arable land by 2030 .

Nouaceur (2016) divided the rainfall trend for Tunisia into three periods:

- From 1970 to 1986 , an absence of trend. This period is characterized by an important variation of the extreme years.

- The second period (1987-2003) is marked by a dry trend that lasts 16 years. The years of the dry and very dry class totaled $55 \%$ of the observations for all the stations.

- The third period (2003-2013) is described as wet. The wet and very humid years total almost $48 \%$ while the dry and very dry years $31.3 \%$.

Climatic data show that average annual temperatures have increased by about $1.4{ }^{\circ} \mathrm{C}$ during the twentieth century, where the warmest temperatures have been recorded since the 1970s. Local warming rates may be higher, for example, in Tunis, temperatures rose by around $3{ }^{\circ} \mathrm{C}$ during the twentieth century (World Bank 2013). Annual totals of rainfall have decreased by 5 percent per decade in northern Tunisia since the 1950s (Fig. 19).

The study on the inflow to major dams during the period from 1947 to 2004 revealed two major conclusions: a decrease in discharge of the period 1976-2004 compared to the period 1947-1975 about 27\% (Lahacher and Pillet 2008).

Deep and shallow aquifers exploitation increased by $333 \%$ and $228 \%$, respectively, between 1968 and 2010. The largest increase occurred before the 1980s (Trabelsi 2016), Fig. 20.
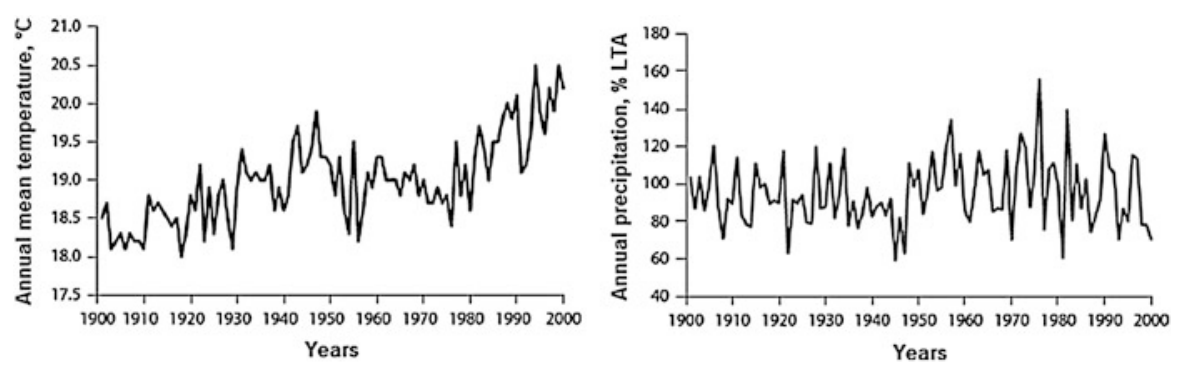

Fig. 19 Average temperatures of the twentieth century and precipitation in Tunisia (Mitchell et al. 2002) 


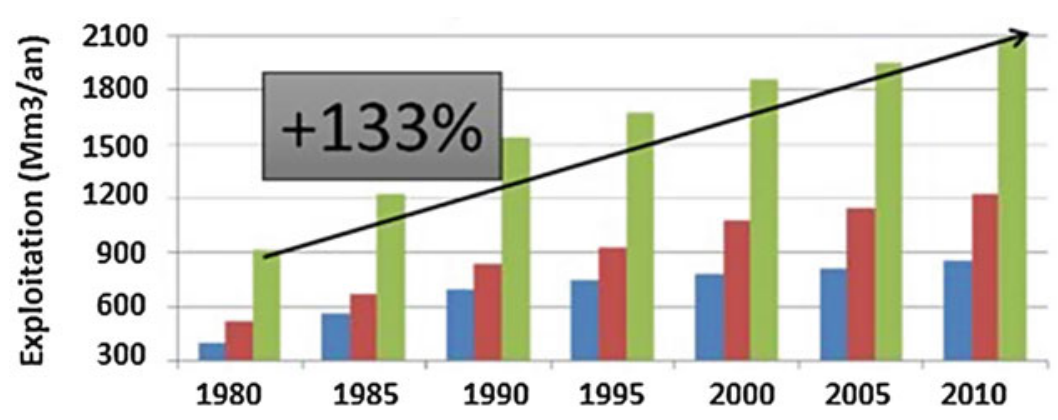

Fig. 20 Evolution of the groundwater exploitation in Tunisia in $\mathrm{Mm}^{3} /$ year (Trabelsi 2016)

The droughts will result from the intensive exploitation of groundwater. The simulation based on the historical evolution of the quality of groundwater resources has led to a decrease of the exploitable groundwater potential equal to $467 \mathrm{~m}^{3}$ in 2030. This quantity corresponds to the volume of water currently overexploited. For deep waters, the reduction will be 517 million $\mathrm{m}^{3}$. The exploitation of deep groundwater will require more energy to pump water (Lahacher and Pillet 2008).

The pressure on water resources will be major. Groundwater, coastal, nonrenewable aquifers will decline from $28 \%$ in 2030 , surface water will decrease by $5 \%$ on the same horizon, and the summer rainfall will increase the lack of soil moisture (Sarra 2009).

\section{Future Projections}

The projections from the HadCM3 model, according to the A2 scenario, show an increase in mean temperature of $1.1^{\circ} \mathrm{C}$ by 2020 and $2.1^{\circ} \mathrm{C}$ by 2050 compared to the 1961-1990 reference period. The largest increases will be in the South, with $1.3^{\circ} \mathrm{C}$ by 2020 and $2.7{ }^{\circ} \mathrm{C}$ by 2050 (TSNCUNFCCC 2013). By 2100, projections of average monthly temperatures show a stronger upward trend over almost regions, the expected increase in temperature is above $2{ }^{\circ} \mathrm{C}$ (Fig. 21). The maximum is expected in the region of Gafsa in southern Tunisia with an increase of $3.91{ }^{\circ} \mathrm{C}$ (Ouasli 2015).

Dry years will become more frequent and intense by 2030, and extremely dry and wet seasons will vary from season to season (TSNCUNFCCC 2013).

The HadCM3 projections for the A2 scenario show a general decrease in average precipitation. This reduction is relatively moderate by 2020 but will become significant by 2050 . In 2020, the decrease in annual rainfall varies between $-5 \%$ in the north and $-10 \%$ in the extreme south (TSNCUNFCCC 2013).

The decrease in rainfall varies between $(-10 \%)$ in the northwest and $(-30 \%)$ in the extreme south of Tunisia by 2050 . Three regions can be distinguished: the extreme west of the country is characterized by a slight decrease in the order of $(-10 \%)$, the south with a significant decrease of about $(-29 \%)$ compared to the third 


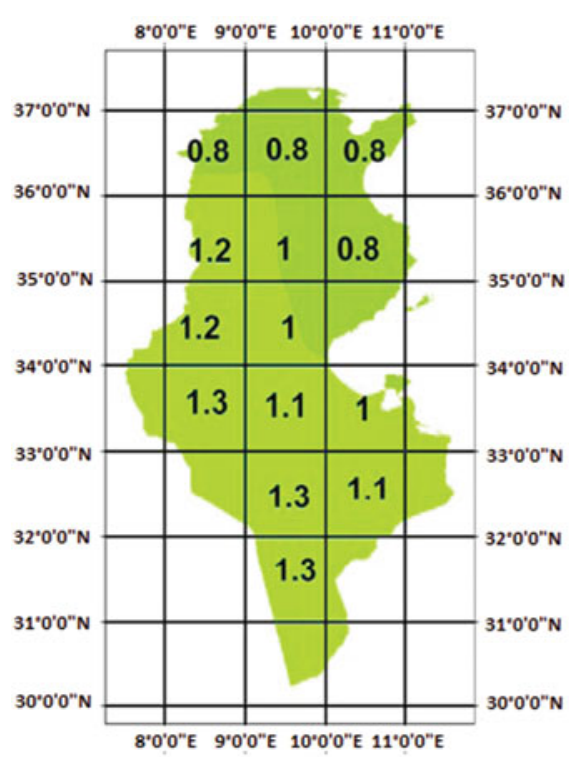

2020

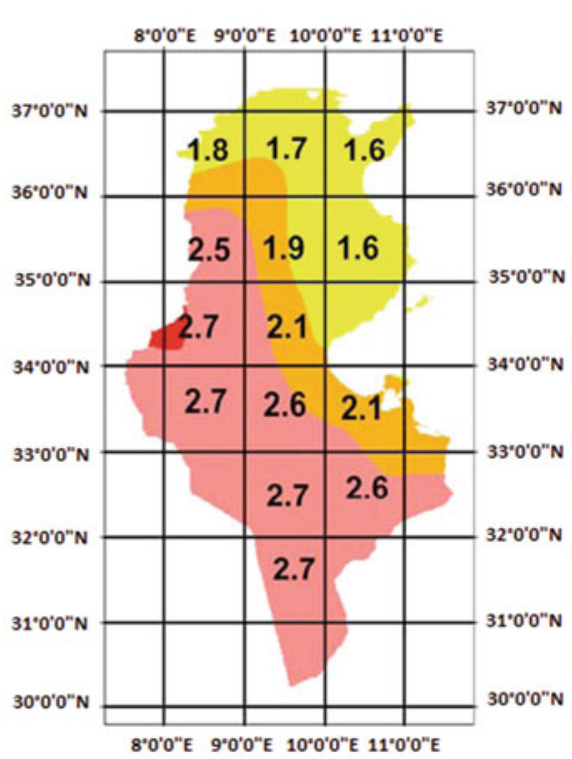

2050

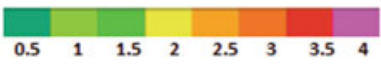

Fig. 21 Temperature $\left({ }^{\circ} \mathrm{C}\right)$ average annual increases in the HadCM3 model (A2 scenario) compared to the reference period in 2020 and 2050 (MARH 2007)

region which includes the rest of the country where the reduction varies between $-12 \%$ and $-16 \%$ (TSNCUNFCCC 2013) (Fig. 22).

For seasonal changes by 2020 , the lowest reduction in precipitation will be recorded in winter $(0 \%$ to $-7 \%)$. The largest drop from $-8 \%$ to $-40 \%$ will occupy the space from north to extreme south in summer (TSNCUNFCCC 2013).

The situation in autumn and spring is intermediate with rainfall decreasing from $-6 \%$ to $-12 \%$ in the extreme south. Seasonal changes are about the same by 2050 (TSNCUNFCCC 2013).

By 2100, future trends in monthly average rainfall are down for all Tunisia (Fig. 23). The maximum decrease is for the Sfax station, located in North East Tunisia, with a percentage of $78.23 \%$. Projections show a strong gradient between trends in the north and those in the south (Ouasli 2015).

Climate projection models show that conventional water resources will decrease by about $28 \%$ by 2030 . This decrease will mainly concern shallow groundwater with high salinity, coastal aquifers, and nonrenewable aquifers. In particular, the reduction of surface water reserves will be around $5 \%$ by 2030 . The confrontation between the available water resources and the increasing demand for water shows that this demand will not be satisfied by 2030 (Fig. 24) without the implementation of more effective conservation and water saving strategies as well as water infrastructure development programs (MARH 2007). Projections of average monthly rainfall over Tunisia show the future evolution of aridity and mark its trend to the north of 

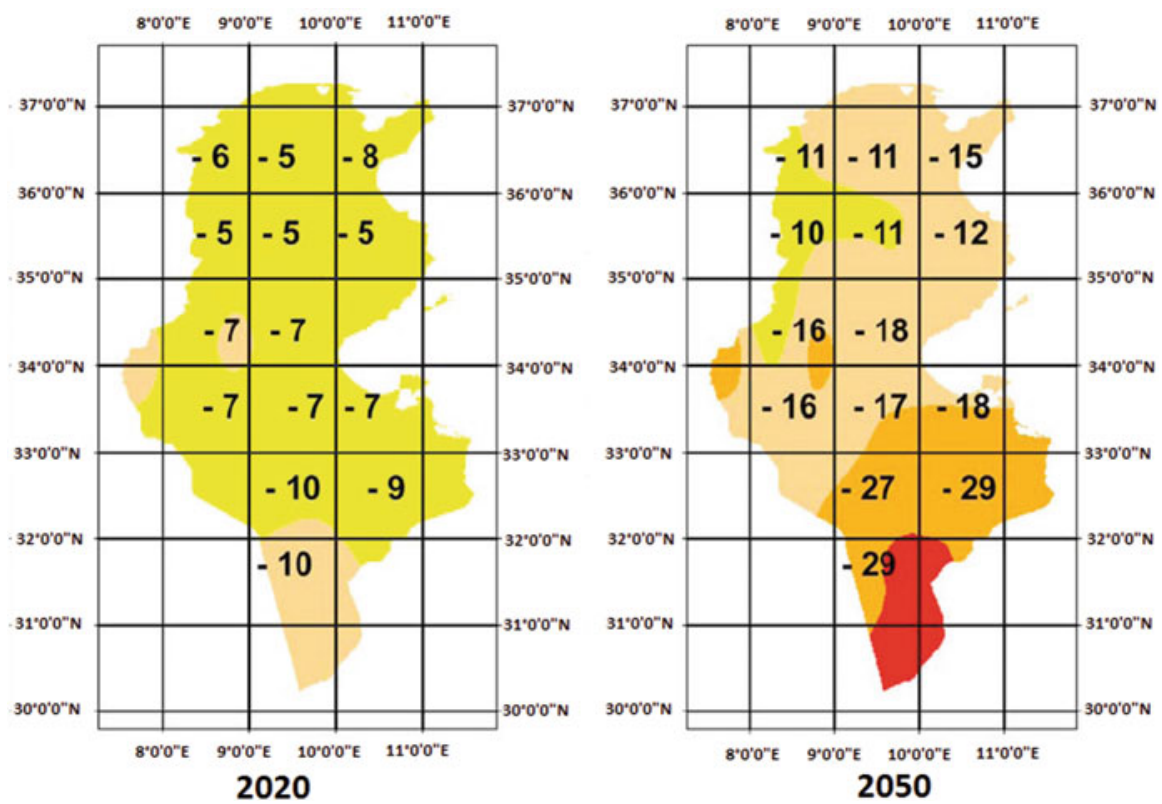

Fig. 22 Decreases of the average annual rainfall in \% of the HadCM3 model (A2 scenario) compared to the reference period by 2020 and by 2050 (GTZ 2007)
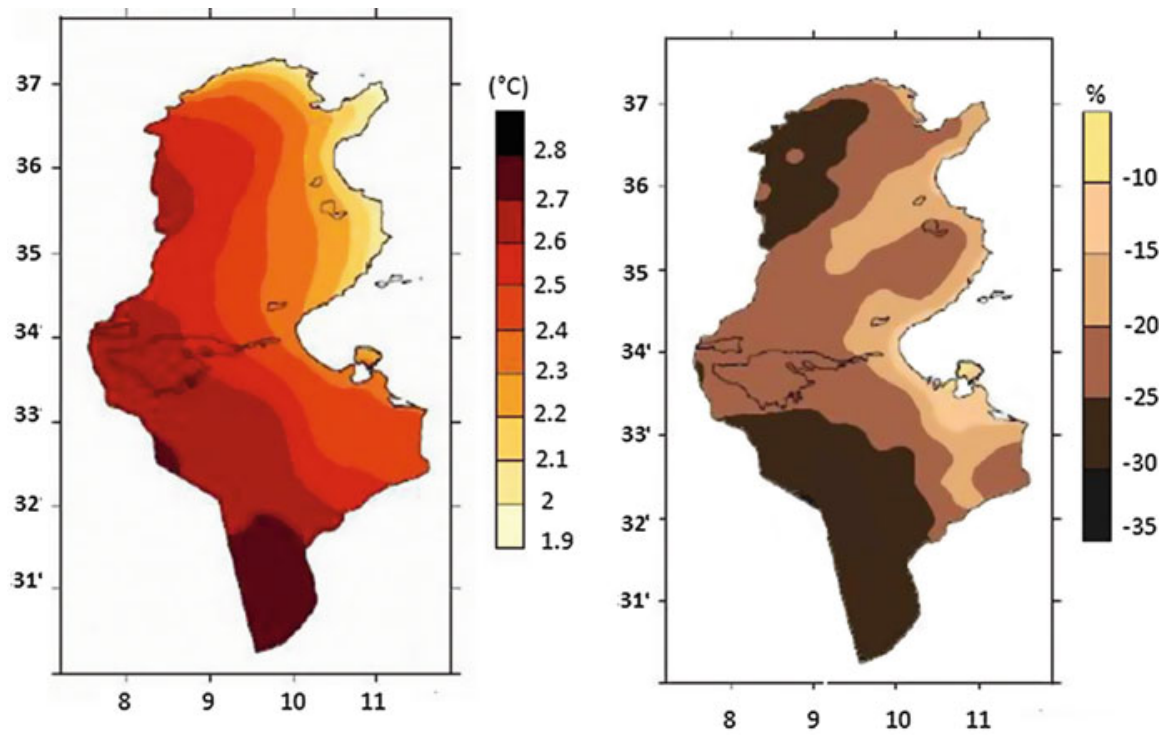

Fig. 23 Projection of temperature and rainfall by 2100 (INM in Ouasli 2015) 


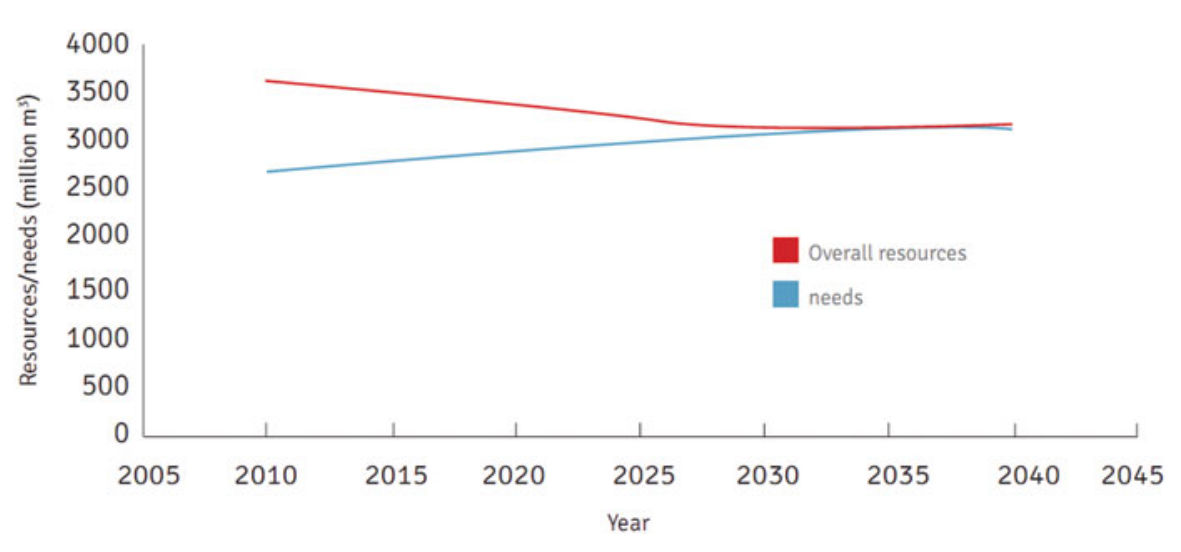

Fig. 24 Evolution (in million $\mathrm{m}^{3}$ ) of overall water resources (in blue) and needs for water (in red) in Tunisia taking into account climate change impacts on water resources (MARH 2007)

Tunisia which shows the vulnerability of the south to water stress in the future (Ouasli 2015).

Recent climate projections confirm the reduction of piezometric levels of the aquifer in the Sfax region located in southeast of Tunisia by 2020 and 2050 for the following two scenarios (Boughariou et al. 2018): the first considers a constant and increasing consumption, the second integrates climate projections published by the Tunisian Ministry of Agriculture and Water Resources and the German Agency for International Cooperation (GIZ), using HadCM3 as a model for general circulation (Boughariou et al. 2018). Both scenarios also indicate the quantitative degradation of the groundwater by 2050 with an alarming marine intrusion (Boughariou et al. 2018).

The projection of water resources, on the basis of various hypotheses proposed, shows that the exploitable conventional water resources will be around 3,829 million $\mathrm{m}^{3}$ in 2030, given that the water management program is carried out entirely (high hypothesis), of $3170 \mathrm{Mm}^{3}$ in the case where only a part of the program will be realized (average hypothesis) and $2718 \mathrm{Mm}^{3}$ and in the case where the program will not be realized (hypothesis low) (TSNCUNFCCC 2013).

The addition of unconventional water resources will strengthen the exploitable resources. This is the desalination of seawater $\left(80 \mathrm{Mm}^{3}\right.$ in the year 2030) and the reuse of treated wastewater $\left(292 \mathrm{Mm}^{3}\right)$ for agricultural needs. The total exploitable in Tunisia in 2030 will be around 4,201 $\mathrm{Mm}^{3}$ (TSNCUNFCCC 2013).

Total water requirements by 2030 are projected at about $2911 \mathrm{Mm}^{3}$ in the case of the low assumption, $3,054 \mathrm{Mm}^{3}$ for the medium hypothesis and 3,743 $\mathrm{Mm}^{3}$ for the high hypothesis. Needs-side assumptions are also defined based on the rate of achievement of the projected programs (TSNCUNFCCC 2013).

In the case where all programs for water mobilization are carried out, the projected needs can be met by 2030 (an excess of about $11 \%$ of the available amount is planned, Table 2). In the case where the planned programs are not all realized, a 


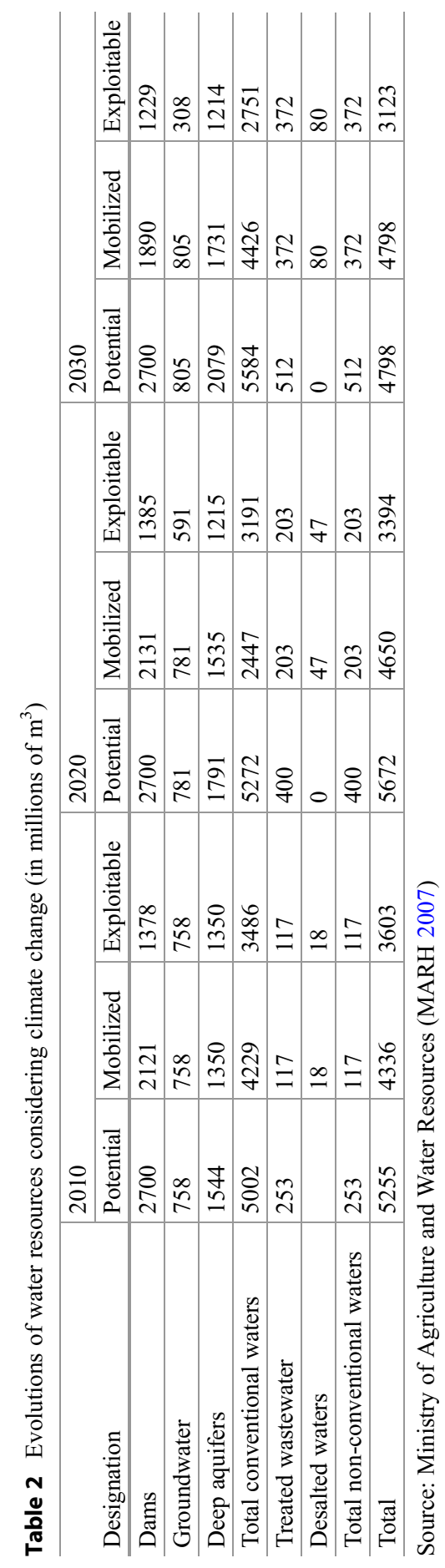




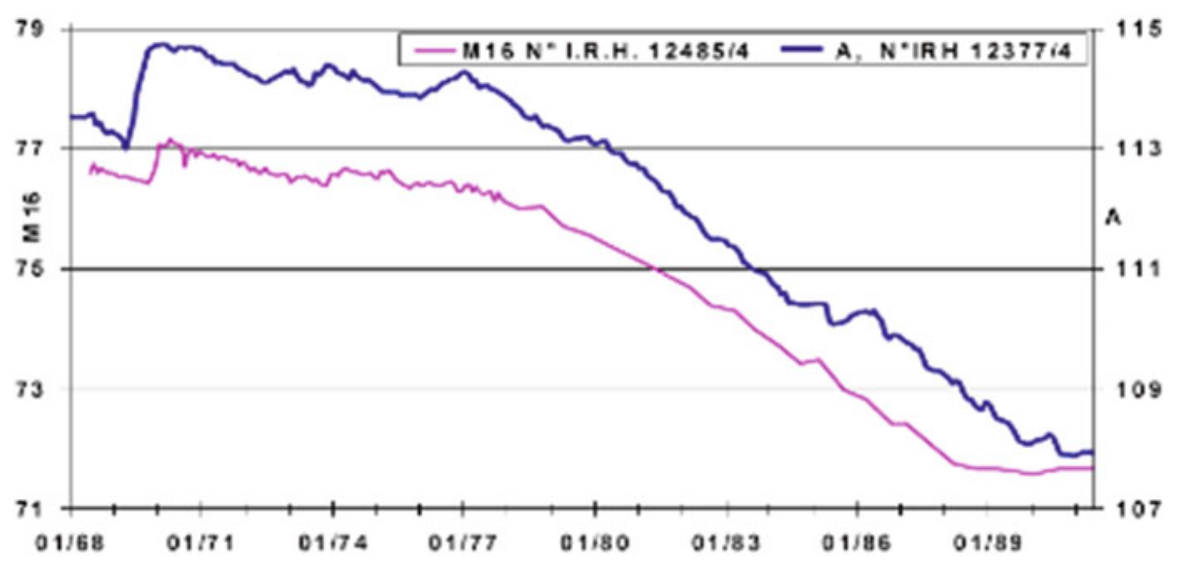

Fig. 25 Decrease of the level of aquifer Merguellil (central Tunisia)

lack of water is likely to appear from 2022 (and this, even if the low hypothesis of the needs side is retained) (TSNCUNFCCC 2013).

If water needs do not evolve as planned and programs to increase the availability of the resource are not realized (low hypothesis), the difference between needs and available water resources would be negative by 2015 (TSNCUNFCCC 2013).

The vulnerability of conventional water resources to climate change in Tunisia is characterized by (Ouasli 2015):

- A reduction of these resources by around $28 \%$ by 2030 . The decrease will affect groundwater, coastal water, and nonrenewable groundwater.

- Increasing frequencies of extreme events: drought and flood.

- The reduction of water volumes in dams by around $5 \%$ by 2030 .

- A deterioration of the quality of surface and underground waters.

- The succession of extreme events: floods and drought.

- The succession of periods of drought. These periods will have an impact on the natural recharge of groundwater. These aquifers will be exposed to overexploitation to compensate the deficit in surface water for irrigation.

\section{Adaptation}

\section{Water Saving Measures}

The main threats to water resources are:

- The overuse of groundwater resources

- Pollution of water resources (rivers, groundwater, etc.). Discharges by solids or liquids into the environment, rivers, and vulnerable groundwater

- The silting of reservoirs 
- The incidence of successive dry years that hinder the annual renewal of water resources

- Water wastage and losses

- The impact of climate change

It was recorded around 20 droughts during the twentieth century. During this period a severe drought is recorded every 6 years.

During the years 1987, 1988, and 1989, Tunisia has experienced the most critical drought. It led to a water deficit around $30 \%$.

In case of drought, the agricultural sector, which currently consumes $81 \%$ of water resources, will suffer water shortages which will result in an increased use of groundwater and can have dramatic effects, since these resources contribute to maximum of $82 \%$ to the satisfaction of agricultural needs (Fig. 25).

To overcome the lack of water in the future, the below directions are to be followed:

- Complete the implementation of works to mobilize water resources to achieve a mobilization rate of $95 \%$

- Integrated management of water resources by capitalizing excess of wet years in order to reduce the effects of drought

- The water conservation and demand management in all sectors

- The use of wastewater in agriculture

- The use of desalination water for drinking water

- The protection of water resources against pollution

- The protection of groundwater against overexploitation (Fig. 25)

The presidential program "Let us rise to the challenges 2009-2014" provides for an increase of $30 \%$ currently to $50 \%$ in 2014 the exploitation rate of treated wastewater in agriculture, industry, and tourism.

Large areas of around 8,500 ha of irrigated crops with treated wastewater will be built within this framework, in the Greater Tunis, Zaghouan, Beja, Sousse, Kairouan, Sfax, Gafsa, Kébili, Gabes, and Tataouine Medenine.

Meanwhile, the authorities will consider the study of potentialities for food, with unconventional resources, groundwater, notably those excessively exploited.

The desalination of water in the majority belongs to the SONEDE for a total capacity of $95,000 \mathrm{~m}^{3}$ (Lahacher and Pillet 2008). Desalination of water is being expanded especially in the tourism sector. New desalination installations based on sea water are programmed by SONEDE in Djerba, Sfax, and Zarrat for a total potential of about $80 \mathrm{~m}^{3}$ in 2030 .

\section{Recommendations}

The following proposed measures may be the best way to cover future water demand (Ouasi 2015; Ben Nouna et al. 2018): 
- Improve the consideration of ecosystems: necessary to ensure adequate recharge of aquifers for the production of good quality of water

- Improvement of water demand management and strengthening of the National Water Saving Program especially water saving for irrigation

- Develop a strategic policy regarding the prediction of extreme events, raising of dams to safeguard their capacity, encouraging the practice of less water-consuming crops

- Quantify the processes of water erosion and siltation rates of dams

- Control of energy consumption during the production of water (pumping, desalination) using clean energies (solar for example)

- Develop integrated management of water resources by basin

- Involve farmers so that they can participate in the future of their water resources

- Enhance knowledge and experience in the field of traditional hydraulic systems

- To further develop the artificial recharge of groundwater

- Development of scientific research related to the water sector

\section{Conclusion}

According to recent studies, the Maghreb countries will become hotspots by the end of the twenty-first century. Higher temperatures and reduced rainfall will increase the frequency of droughts in these countries. The drought observed in recent decades has tragic consequences. These effects are reflected by lower inflows to dams with more than $30 \%$ reduction in dam volumes and the lower level of groundwater sometimes with $40 \mathrm{~m}$ of drawdown in the plain of Mitidja in Algeria for example. This latter is the combined effect of drought and overexploitation of groundwater. This overexploitation is due to the decrease of the natural recharge and the increase of the water demand (Increasing demography and economic and social development).

The decrease in rainfall, as the lag time of rainy seasons, has penalized development projects particularly related to agriculture and affect the proper functioning of the carried out infrastructure.

To mitigate the impacts of climate change in the region, we recommend the integration of climate change in the programs and policies particularly in the context of sustainable development. It must also take into account the weather, and reinforce the measures of Weather assistance in the rural areas and to all users.

The undeniable effects of drought on reducing the level of production of cereals in particular require from planners to take into account the continuing risks associated with an arid climate and the risks of seasonal drought in all aspects of agricultural development. Thus the long dry season causes prolonged water stress to be taken into account in the selection of appropriate crops and varieties.

For the three countries, many projects and programs are developed and implemented to cope with the effects of climate change and Anthropic. These countries are also facing rapid population growth and sustained socioeconomic development. Agriculture is the cornerstone of this development, which will increase 
the demand for water. The water infrastructure programs must take into account this strategy which will ensure the food security of these three Maghreb countries.

In order to meet this ever increasing demand for water, especially for agriculture, it is necessary to set up special programs and develop irrigation techniques to reduce the consumption of water resources in agriculture. These programs should also make it possible to increase agricultural production to ensure food security in these three countries. Also, the reduction of water leakage from drinking water supply networks that are important in the order of 30 to $40 \%$. The fight against water scourge makes it possible to create new irrigated perimeters and to effectively supply the population with drinking water.

\section{References}

Agoumi A (2003) Vulnérabilité des pays du Maghreb face aux changements climatiques. International Institute for Sustainable Development (IISD), Winnipeg. $11 \mathrm{p}$

Alaoui M (2013) Water sector in Morocco: situation and perspectives. J Water Resour Ocean Sci 2 (5):108-114

Ameur $\mathrm{F}$ (2017) Construction de la surexploitation et reproduction des inégalités d'accès et d'usage des eaux souterraines. Thèse de doctorat. AgroParisTech, France.

Amraoui F (2019) Integrated management of water resources as a response to the water deficit: Case of the Saiss Plain (Morocco). International conference "groundwater resilience to climate change and high pressure" GRECPIMA 2019. May -8-10, 2019, Muğla, Turkey

Bct (2007) Rapport annuel de la banque centrale de Tunisie. Ministère du Développement et de la Coopération Internationale de Tunisie. 70 p. https://www.apbt.org.tn/wp-content/uploads/2016/ 06/rapport_fran_2007_t1.pdf

Ben Abdelfadel A, Driouech F (2008) Climate change and its impacts on water resources in the Maghreb region. 13èmeCongrèsMondial de l'Eau, 1-4 septembre, Montpellier, France

Ben Nouna B, Rezig KS, Chebil A, Jebari S (2018) Water resources and climate change: key adaptation strategies and the role of scientific research in Tunisia. J New Sci Agricult Biotechnol 51(1):3138-33147

Boughariou E, Allouche N, Jmal I, Mokadem N, Ayed B, Hajji S, Khanfir H, Bouri S (2018) Modeling aquifer behaviour under climate change and high consumption: Case study of the Sfax region, southeast Tunisia. J Afr Earth Sci 141:118-129. https://doi.org/10.1016/j.jafrearsci. 2018.02.006

Chebil A, Souissi A, Frija A, Stambouli T (2019) Estimation of the economic loss due to irrigation water use inefficiency in Tunisia. Environ Sci Pollut Res 26:11261-11268. https://doi.org/10. 1007/s11356-019-04566-8

Choukr-Allah R. Comparative study between Moroccan water strategies and WFD. In: Junier S, El Moujabber M, Trisorio-Liuzzi G, Tigrek S, Serneguet M, Choukr-Allah R, Shatanawi M, Rodríguez R (eds) Dialogues on Mediterranean water challenges: Rational water use, water price versus value and lessons learned from the European Water Framework Directive. Bari : CIHEAM, 2011. p. 181-188 (Options Méditerranéennes : Série A. Séminaires Méditerranéens; n. 98)

Dahan S (2017) Managing urban water scarcity in Morocco. World Bank, Washington, DC

Demmak A (2008) La sècheresse en Algérie des années 1975/2000. Second meda water regional event on local water management, Marrakech, morocco, 28, 29 \& 30 April 2008

Driouech F (2010) Distribution des précipitations hivernales sur le Maroc dans le cadre d'un changement climatique: Descente d'échelle et incertitudes. PhD thesis University of Toulouse (France), $163 \mathrm{p}$

Droogers P, Immerzeel W W, Terink W, Hoogeveen J, Bierkens MFP, Van Beek LPH, Debele B (2012). Water resources trends in Middle East and North Africa towards 2050. Hydrol Earth 
Syst Sci, 16, 3101-3114., http://www.hydrol-earth-syst-sci.net/16/3101/2012/. https://doi.org/ 10.5194/hess-16-3101-2012

El Hafid D, Zzerrouqi Z, Akdim B (2017) Study of drought sequences in the Isly basin (East Morocco). Larhyss J 31:83-94

Elloumi F (2016) La gouvernance des eaux souterraines en Tunisie. IWMI projectreport $n^{\circ} 7$. Groundwater governance in the Arab World. 2016. $121 \mathrm{p}$

Farzaneh MR, Eslamian S, Mirnezami SJE (2014) Chap 8 Climate change: uncertainty, impact, and adaptation. In: Eslamian S (ed) Handbook of engineering hydrology, Vol. 2: modeling, climate changes and variability. Francis and Taylor, CRC Group, Boca Raton, pp 127-146

Giorgi F (2002) Variability and trends of sub-continental scale surface climate in the twentieth century. Part I: observations. Clim Dyn 18:675-691. https://doi.org/10.1007/s00382-001-0204-x

GTZ (2007) Stratégie Nationale d'Adaptation de l'Agriculture Tunisienne et des écosystèmes aux changements climatiques. Deutsche Gesellschaft für Internationale Zusammenarbeit (GIZ) GmbH. 150 p. http://www.environnement.gov.tn/PICC/wp-content/uploads/Strat\%C3\%A9gienationale-d $\% \mathrm{E} 2 \% 80 \% 99$ adaptation-de-1\%E2\%80\%99agriculture.pdf

Habibi B, Meddi M, Torfs PJJF, Remaoun M, Van Lanen HAJ (2018) Characterisation and prediction of meteorological drought using stochastic models in the semi-arid Chéliff-Zahrez basin (Algeria). J Hydrol Reg Stud 16:15-31. https://doi.org/10.1016/j.ejrh.2018.02.005G

Haddour A, Mahé G, Meddi M (2019) Impact des changements climatiques sur la ressource en eau dans trois grands bassins versants du centre et de l'ouest de l'Algérie. Séminaire international sur l'hydrogéologie et l'environnement. 12-14 mars 2019, Ouargla (Algérie)

Hallouz F, Meddi M, Mahe G (2013) Modification du régime hydroclimatique dans le bassin de l'oued mina (nord-ouest d'Algérie) - changes of the hydroclimaticregime in the basin of the Wadi mina (northwestAlgeria). Revue des Sciences de l'Eau 26(1):33-38. https://doi.org/10. $7202 / 1014917$ ar

Hamza M (2007) Gestion des ressources en eau en Tunisie. ineco- Nabeul, le 6 décembre 2007. http://environ.chemeng.ntua.gr/ineco/UserFiles/File/TunisiaWorkshop/Gestion\%20des\% 20 ressources $\% 20$ en $\% 20$ eau $\% 20$ en $\% 20$ Tunisie.pdf

INDC (2015) Morocco's intended nationally determined contribution, 36 p. https://www4.unfccc. int/sites/submissions/INDC/Published\%20Documents/Morocco/1/Morocco\%20INDC\%20sub mitted $\% 20$ to $\% 20$ UNFCCC $\% 20-\% 205 \% 20$ june $\% 202015$.pdf

IPCC (2013) Summary for policymakers. In: Stocker TF, Qin D, Plattner G-K, Tignor M, Allen SK, Boschung J, Nauels A, Xia Y, Bex V, Midgley PM (eds) Climate change 2013: the physical science basis. Contribution of working group I to the fifth assessment report of the intergovernmental panel on climate change. Cambridge University Press, Cambridge/New York, pp $3-30$

Jacobeit J (2000) Rezente Klimaentwicklung im Mittelmeerraum. Petermanns Geogr Mitt 144:22-33

Kahlerras M, Meddi M, Benabdelmalek M, Tumi S, Kahlerras D, Nouiri I (2018) Modeling water supply and demand for effective water management allocation in Mazafran basin (north of Algeria). Arab J Geosci 11(18):1-12

Khomsi K, Mahe G, Sinan M, Snoussi M (2013) Hydro-climatic variability in two Moroccan watersheds: a comparative analysis of temperature, rain and flow regimes. In: Boegh E, Blyth E, Hannah DM, Hisdal H, Kunstmann H, Su B, Yilmaz KK (eds) Climate and land surface changes in hydrology, vol 359. IAHS Publications, Wallingford, pp 183-190

Knippertz P, Christoph M, Speth P (2003) Long-term precipitation variability in Morocco and the link to the large-scale circulation in recent and future climates. Meteorog Atmos Phys 83:67-88. https://doi.org/10.1007/s00703-002-0561-y

Lahacher RG, Pillet G (2008) Projection des ressources en eau de la Tunisie sous les effets des changements climatiques globaux. XIIIth World Water Congress, 1-4 septembre, Montpellier, France

MARH (2007) (Ministère de l'Agriculture et des Rein climate change 2013 ssources Hydrauliques de Tunisie). Stratégie Nationale d'Adaptation de l'Agriculture Tunisienne et des écosystèmes 
aux changements climatiques. Bureaux d'études GOPA et Exa Consult Tunisie, janvier 2007. $150 \mathrm{p}$

Matari A (2016) Climat et changement climatique. Journal Algérien des Régions Arides (jara), Numéro Special, 2016

MDCE (2016) Troisième communication Nationale du Maroc à la convention cadre des nations unies sur le changement climatique. Ministère Délègue Auprès du Ministère de l'Énergie, des Mines, de l'Eau et de l'Environnement Chargé de l'Environnement, Avril 2016. https://unfecc. int/resource/docs/natc/marnc3.pdf

Meddi M, Boucefiane A (2009) Impact of Climate Change on the renewal of underground water resources (Case Hydrographic Basin Chéliff-Zahrez). Groundwater and Climate in Africa (Proceedings of the Kampala Conference, June 2008). IAHS Publication, 334

Meddi M, Hubert P (2003) Impact de la modification du régime pluviométrique sur les ressources en eau du Nord-ouest de l'Algérie. In: Servat E, et al., eds. Hydrology of Mediterranean and semi-arid regions. Wallingford: IAHS Press, IAHS. Publ. 278, 229-235. Disponible á: http:// iahs.info/redbooks/a278/iahs_278_229.pdf

Merabti M, Martins DM, Meddi M, Pereira IS (2018) Spatial and time variability of drought based on SPI and RDI with various time scales. Water Resour Manag 32:1087-1100. https://doi.org/ 10.1007/s11269-017-1856-6

Mitchell TD, Hulme M, New M (2002) Climate data for political areas. Area 34:109-112. http:// www.cru.uea.ac.uk/timm/data/index-table.html

New M, Todd M, Hulme M, Jones P (2001) Precipitation measurements and tends in the twentieth century. Int J Climatol 21:1899-1922

Nouaceur Z (2016).Analyse de la variabilite pluviometrique sur près d'un demi-siècle au Maghreb central (Maroc, Algérie, Tunisie). XXIXe Colloque de l'Association Internationale de Climatologie, Lausanne - Besançon

OSS (2009) Vers un système d'alerte précoce à la sécheresse dans 3 pays de la rive sud de la Méditerranée. Collection de Synthèse nº 4. OSS - Tunis 2009. 86 p. http://www.oss-online.org/ cd_envi/doc/07/03/06.pdf

Ouasli A (2015) Secteur de l'eau en face des changements climatiques (cc). Forum scientifique "innovation dans le secteur agricole et le défi du changement climatique". Bureau de Planification et des Equilibres Hydrauliques. République Tunisienne, Ministère de l'Agriculture, des Ressources Hydrauliques et de la Pêche. http://www.siat.tn/medias/files/ siat-2016/interventions/2-2-Secteur-de-1-Eau.pdf

Rodrigo FS, Trigo RM (2007) Trends in daily rainfall the Iberian Peninsula from 1951 to 2002. Int J Climatol 27:513-529

Sarra A (2009) Projections, impacts et stratégies d'adaptation. https://www.webmanagercenter. com/2009/08/26/79540/tunisie-changement-climatique-projections-impacts-et-strategies-dadaptation-3-3/

SCNCCRM (2009) Seconde Communication Nationale à la Convention Cadre des Nations Unies sur les changements climatiques du royaume du Maroc. Ministère de l'Aménagement du Territoire, de l'Urbanisme, de l'Habitat et de l'environnement, 2009. $217 \mathrm{p}$

SIGMA (2017) L'eau en Tunisie entre enjeux stratégiques et qualité de vie des citoyens. Les rtencontres de Tunis, Conférence - débat. 28 septembre 2017

Sinan M, Belhouji A (2016) Impact of the climate change on the climate and the water resources of Morocco on horizons 2020, 2050 and 2080 and measures of adaptation. La Houille Blanche 4:32-39

Sinan M, Boussetta M, El Rherari A (2009). Changement climatique: causes et conséquences sur le climat et les ressources en eau. J HTE 142 21-30

Taabni M, El Jihad MD (2015) Eau et changement climatique au Maghreb: quelles stratégies d'adaptation? Les Cahiers d'outre-Mer 65(260):493-518

Trabelsi F (2016) Impact du changement climatique sur les ressources en eau souterraine et politiques d'adaptation en Tunisie. Project: Tempus IV: Building Climate Change Adaptation in Morocco, Algeria and Tunisia "Climadapt" 
Tramblay Y, El Adlouni S, Servat E (2013) Trends and variability in extreme precipitation indices over Maghreb countries. Nat Hazards Earth Syst Sci 13:3235-3248. https://doi.org/10.5194/ nhess-13-3235-2013

TSNCUNFCCC (2013) Tunisia's second national communication under the United Nations framework convention on climate change (UNFCCC). 174 p., 2013. http://www.unfccc.int/resource/ docs/natc/tunnc2.pdf

World Bank (2013) La Tunisie face aux changements climatiques. Évaluation et Actions pour accroitre la résilience et le développement. 2010. $174 \mathrm{p}$

World Bank (2017) Beyond scarcity: Water security in the Middle East and North Africa. MENA development report. World Bank, Washington, DC. Licence: CC BY 3.0 IGO https:// openknowledge.worldbank.org/handle/10986/27659

World Bank Group (2017a) Climate variability, drought, and drought management in Morocco's agricultural sector in Morocco. http://documents.worldbank.org/curated/en/ 353801538414553978/Climate-Variability-Drought-and-Drought-Management-in-MoroccosAgricultural-Sector

World Bank Group (2017b) Managing urban water scarcity in Morocco. World Bank, Washington, DC. (C) World Bank. https://openknowledge.worldbank.org/handle/10986/29190. License: CC BY 3.0 IGO

Zeroual A (2017) Evolution du climat passé récent et futur en algérie. PhD thesis, ENSH, Blida, $2017,250 \mathrm{p}$

Zeroual A, Assani Ali A, Meddi M (2017) Combined analysis of temperature and rainfall variability as they relate to climate indices in northern Algeria over the 1972-2013 period. Hydrol Res 48(2):584-595

Open Access This chapter is licensed under the terms of the Creative Commons Attribution 4.0 International License (http://creativecommons.org/licenses/by/4.0/), which permits use, sharing, adaptation, distribution and reproduction in any medium or format, as long as you give appropriate credit to the original author(s) and the source, provide a link to the Creative Commons license and indicate if changes were made.

The images or other third party material in this chapter are included in the chapter's Creative Commons license, unless indicated otherwise in a credit line to the material. If material is not included in the chapter's Creative Commons license and your intended use is not permitted by statutory regulation or exceeds the permitted use, you will need to obtain permission directly from the copyright holder.

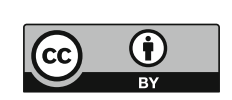

